\title{
O USO DA LEGISLAÇAO AMBIENTAL NA RESTAURAÇÃO DA CONECTIVIDADE ESTRUTURAL DA PAISAGEM: UM ESTUDO DE CASO PARA A BACIA HIDROGRÁFICA DO CORREGO DAS POSSES, EXTREMA-MG
}

\author{
Thiago Salomão de Azevedo ${ }^{1}$
}

Resumo: No Brasil, a estratégia governamental para garantir o uso sustentado dos recursos naturais em propriedades privadas está baseada na adoção de medidas de comando e controle estabelecidas pelo Código Florestal, sob a forma de Áreas de Preservação Permanente (APP). Considerando esta premissa, o objetivo principal deste trabalho foi verificar se, com o cumprimento da legislação ambiental brasileira estabelecida no Código Florestal, com referência as APP's, é possível restabelecer a conectividade estrutural da paisagem, tomando como exemplo a bacia do córrego das Posses, localizada no município de Extrema-MG. A metodologia empregada neste trabalho foi embasada no estabelecimento de critérios que fundamentaram a localização das áreas prioritárias de APP's. Através da utilização de geotecnologias, tais critérios foram espacializados, originando cenários que mostram o grau de degradação da paisagem. Os resultados mostraram que nas Áreas de Preservação Permanente a legislação ambiental não está sendo cumprida. Entretanto, para a bacia das Posses, a regularização das propriedades com relação ao Código Florestal não é suficiente para manter a conectividade da paisagem, pois ainda assim a área de matas não atinge o limite mínimo exigido para que a mesma percole.

Palavras Chave: Código Florestal; Geotecnologias; Paisagem; Restauração Ecológica; Extrema.

\section{THE USE OF ENVIRONMENTAL LEGISLATION IN THE RESTORATION OF THE STRUCTURAL CONNECTIVITY OF THE LANDSCAPE: A STUDY CASE FOR THE POSSES STREAM, EXTREMA-MG}

Abstract: The government strategy to ensure the sustainable use of natural resources on private lands in Brazil is based on the adoption of the command and control measures established by the Forest Code under the form of Permanent Preservation Areas (PPA). The main purpose of this study is to verify if it would be possible to restore the structural connectivity of Posses watershed landscape located in Extrema municipality, Minas Gerais State, by the enforcement of the environmental legislation established in Brazil Forest Code with reference to PPA. The methodology used in this study was based on designations of criteria that

\footnotetext{
${ }^{1}$ Doutor em Geografia - Universidade Estadual Paulista (UNESP Rio Claro). E-mail: azevedots@gmail.com Estudos Geográficos, Rio Claro, 15(2): p-p, jul./dez. 2017 (ISSN 1678-698X)

http://www.periodicos.rc.biblioteca.unesp.br/index.php/estgeo
} 
substantiated the allocation of priority areas of PPA. These criteria were spatialized through the usage of geotechnologies, creating scenarios that show landscapes degradation. The results demonstrate that in Permanent Preservation Areas the environmental legislation is not being enforced. However, for Posses watershed area, the regularization of the properties regarding to the Forest Code is not sufficient to maintain the landscape connectivity since forested areas still does not reach the minimum required for it to percolate.

Keywords: Brazilian Forest Code; Geotechnologies; Landscape; Restoration Ecology; Extrema.

\section{INTRODUÇÃO}

Os ecossistemas naturais vêm sofrendo perturbações ambientais desde o momento em que o fogo e a caça começaram a ser utilizados. Com a domesticação de plantas e animais, o desmatamento se deu progressivamente, provocando uma rápida diminuição da cobertura vegetal natural, principalmente nas regiões tropicais e subtropicais. Apenas para nos reportarmos a tempos mais recentes, no período de 1990 a 2000, o desmatamento mundial das florestas tropicais foi estimado em 167.200.000 de hectares. Na América do Sul, no mesmo período, o desflorestamento foi de 37.200.000 hectares, sendo que somente no Brasil, foram devastados 23.000.000 de hectares de florestas (FAO, 2001). Esta alteração possibilita a fragmentação da paisagem que, desta forma, passa a ser composta por mosaicos de vegetação nativa estruturados em fragmentos florestais de diferentes dimensões e formas (AZEVEDO, 2003).

A estrutura e a dinâmica da fragmentação da paisagem variam em função de uma série de fatores como: o histórico de perturbação; a forma dos fragmentos; o tipo de vizinhança e o grau de isolamento. A paisagem fragmentada apresenta uma série de características que a diferenciam da paisagem contínua da qual se originou e, dependendo destas características, pode sofrer maior ou menor alteração (SHELHAS; GREENBERG, 1996).

Dentre as inúmeras alterações que a paisagem fragmentada sofre, o aspecto mais grave da fragmentação florestal é a perda de diversidade, que ocorre através da modificação da sua estrutura física. Um dos fatores que mais afetam os fragmentos é o efeito de borda (VIANA; TABANEZ, 1997) que, segundo Forman e Godron (1986), é definido como uma alteração na composição e ou na abundância relativa de espécies na parte marginal de um fragmento, causando alterações estruturais. A vegetação localizada nas bordas passa a ser afetada por um aumento intenso da radiação solar e de ventos, que causam aumento da temperatura e diminuição da umidade do solo. A fragmentação, ao mudar o microclima da floresta, pode favorecer o desenvolvimento das espécies pioneiras, comprometendo a estrutura dos fragmentos.

O efeito de borda também afeta o comportamento da fauna como, por exemplo, a elevação das taxas de predação em ninhos (TABANEZ, 1995). Desta forma, para minimizar os efeitos dos processos de fragmentação e degradação, é necessário efetuar o manejo adequado da paisagem. Atualmente, segundo 
Kageyama et al. (2003), esta estratégia é denominada de restauração ecológica de ecossistemas naturais ou, simplesmente, de restauração florestal.

A definição de restauração ecológica adotada pela "Society for Ecological Restoration" é a ciência, prática e arte de assistir e manejar a recuperação da integridade ecológica dos ecossistemas, incluindo um nível mínimo de biodiversidade e de variedade na estrutura e no funcionamento dos processos ecológicos, considerando se seus valores ecológicos, econômicos e sociais (ENGEL; PARROTTA, 2003, p. 6). Esta definição considera que restaurar um ecossistema não é copiar exatamente um modelo da natureza, mas recuperar a estabilidade e a integridade do ecossistema, almejando recriar comunidades ecologicamente viáveis, protegendo e fomentando a capacidade natural de mudança dos ecossistemas, resgatando a harmonia entre o homem e o meio (ENGEL; PARROTTA, 2003).

Para Metzger (2003), a restauração ecológica pode ter objetivos diversos dependendo da escala de abordagem. Por exemplo, escalas espaciais mais amplas (regional ou até mesmo continental), que englobam um conjunto de ecossistemas, devem ser consideradas como áreas prioritárias, pois embora degradadas, têm reconhecido valor biológico, como os "hot-spots" de biodiversidade, refúgios ecológicos e áreas com alto grau de endemismo. Já em uma escala mais pontual (propriedades privadas), as áreas prioritárias sugeridas para a restauração são as áreas onde o uso do solo é inadequado.

Segundo Doremus (2003), existem inúmeras estratégias, de ação governamental para se efetuar a conservação e a restauração dos ecossistemas naturais em propriedades privadas. Nos Estados Unidos, por exemplo, as cinco principais estratégias são:

1- Programas educacionais embasados por campanhas conservacionistas de agências ambientais;

2- A compra dos direitos de uso da terra privada pelo governo;

3- O incentivo econômico, isto é, os proprietários que efetuarem a conservação dos ecossistemas naturais podem receber compensações do governo na forma de perdão de dívidas, redução nas taxas de créditos e até na forma de remuneração monetária;

4- A criação de mercados para a conservação, por exemplo, a negociação de créditos de carbono e o ecoturismo;

5- Proibições e restrições de uso. Neste caso, o não cumprimento das normas estabelecidas implica em multa, no confisco de bens e na suspensão de contratos com o governo.

Segundo Ranieri (2004), na Costa Rica, as questões relativas à preservação dos recursos naturais estão baseadas na Lei 7.761-98, que estabelece medidas de controle de uso do solo em propriedades particulares visando a preservação florestal. Esta lei estabelece a proibição da supressão da cobertura vegetal das 
áreas de proteção e o direito de receber remuneração por serviços ambientais prestados aos proprietários que mantiverem a vegetação florestal.

No Brasil, a estratégia governamental para a restauração e a conservação dos ecossistemas, em propriedades privadas, está baseada na adoção de medidas de comando e controle estabelecidas pelo Código Florestal, sob a forma de Áreas de Preservação Permanente (APP) e as Reservas Legais (RL).

Considerando o quadro apresentado, o objetivo principal deste trabalho foi o de verificar se, com o cumprimento da legislação ambiental brasileira estabelecida no Código Florestal, com referência às Áreas de Preservação Permanentes, é possível restabelecer a conectividade estrutural da paisagem, tomando como exemplo a bacia do córrego das Posses, localizada no município de Extrema-MG. Esta bacia hidrográfica é uma das sub-bacias das cabeceiras do Jaguari, apresenta um estágio de degradação elevado, sendo considerada a bacia hidrográfica mais degradada do Município de Extrema (EXTREMA, 2006). A adoção da bacia hidrográfica como unidade de estudo, como forma de reordenar a utilização, organização espacial e administração dos recursos naturais se assenta nas indicações do Conselho Nacional do Meio Ambiente - CONAMA que, pela Resolução 020/86, estabelece a bacia hidrográfica como unidade básica para estudos de impacto ambiental (BRASIL, 1986).

Do ponto de vista científico, segundo Montgomery et al. (1995) e Kageyama et al. (2007), a escolha da bacia hidrográfica como unidade de estudo deve-se ao fato de que ela possui limites bem definidos, o que permite o entendimento das interações ecológicas com a dinâmica da paisagem, pelo estabelecimento das relações de causa e efeito entre as atividades de uso e a degradação ambiental, considerando o fato de que, muitas vezes, a mesma ação, quando implementada em diferentes locais da bacia, pode resultar em impactos diferentes.

\section{A RESTAURAÇÃO DA CONECTIVIDADE DA PAISAGEM}

A quantificação da dinâmica da paisagem através de métodos de análise espacial que integrem os domínios espaciais e temporais permite analisar, interpretar e simular os processos ecológicos no nível da paisagem (TURNER et al., 2001). Turner e Gardner (1990) salientam que os índices que quantificam a dinâmica da paisagem podem providenciar uma medida apropriada para o monitoramento dos processos ecológicos. Para Ranieri (2004), os índices relativos à estrutura da paisagem que permitem a comparação de diferentes paisagens ao longo do tempo, correlacionando com os processos ecológicos são: a área dos fragmentos, o isolamento dos fragmentos, e a conectividade dos habitats.

Segundo Forman e Godron (1986), estes parâmetros são importantes indicadores do controle e da manutenção dos ecossistemas, pois estudos dessa natureza podem ser incorporados em planos de recuperação e de manejo de paisagens degradadas (REX; MALANSON, 1990; LI 2000;). Forman e Godron (1986) sugeriram, ainda, que o tamanho dos fragmentos das paisagens é um indicador de vulnerabilidade da estrutura dos fragmentos florestais, sendo que existe uma relação entre o tamanho do fragmento e o número de espécies que se espera 
encontrar nele (MacARTHUR; WILSON, 1967). Assim, o tamanho do fragmento florestal fornece subsídios que resultam em indicadores da estrutura da paisagem (ARAÚJO, 2007).

Segundo Ranieri (2004), a importância dos fragmentos florestais com grandes extensões deve-se à relação entre o tamanho e a existência de áreas centrais, isto é, quanto maior for o fragmento florestal, maior será sua probabilidade de possuir uma área central não influenciada e com maior possibilidade de abrigar espécies mais dependentes de habitats inalterados. Outro aspecto importante relacionado ao tamanho do fragmento florestal é a sua forma geométrica, que pode estar relacionada com a intensidade de perturbação antrópica na paisagem (FORMAN; GODRON, 1986; FORMAN, 1995; PICKETT; KEVIN, 1997).

Um dos mais importantes efeitos da forma dos fragmentos está relacionado com o efeito de borda, uma vez que a geometria do fragmento altera a composição e a abundância relativa de espécies nas porções marginais, modificando a sua estrutura ecológica (FORMAN; GODRON, 1986). Segundo Tabarelli et al. (1999) e Laurence (1991), a borda é o local onde se iniciam grande parte dos processos ligados à fragmentação florestal, pela alteração na luminosidade, na temperatura, na velocidade de vento, entre outros, que determinam aumento na densidade de espécies ruderais (Solanaceae, Compositae, Leguminosae e Euphorbiaceae).

Para Tabarelli et al. (1999), a espécie ruderal é um bom indicador de perturbações ambientais, considerando que o sucesso do estabelecimento destas espécies depende da intensidade da ação antrópica (principalmente atividades agrícolas) e dos distúrbios naturais como fogo e deslizamentos.

Além do tamanho do fragmento, o grau de isolamento é outro indicador estrutural da perda de diversidade na paisagem. Segundo Viana et al. (1992), estas modificações dependem do grau de isolamento dos fragmentos, que pode dificultar ou impedir o influxo (migração) de animais, pólen e sementes, isto é, fragmentos florestais isolados não permitem que as espécies se comuniquem com áreas vizinhas, impossibilitando o fluxo gênico. A noção básica que se opõe ao isolamento florestal é a de conectividade, que se define como sendo a capacidade de uma paisagem em facilitar os fluxos biológicos (METZGER, 2003).

Para Wiens et al. (1997), esta definição possui dois aspectos distintos - o estrutural e o funcional. $\mathrm{O}$ aspecto estrutural (espacial) refere-se à fisionomia da paisagem em relação à complexidade do arranjo espacial dos fragmentos florestais, da densidade e da complexidade dos corredores e da permeabilidade da matriz ${ }^{2}$.

O aspecto funcional está relacionado à resposta biológica específica de cada espécie, à estrutura da paisagem. Para Metzger (2003, p. 52), "a conectividade estrutural pode ser considerada um potencial de conectividade funcional", isto é, o estabelecimento de corredores não é condição sine qua nom para que exista a funcionalidade, ou ainda, a ausência de corredores (conexão) espaciais não implica na ausência de fluxos biológicos. "Tudo depende das características de cada

\footnotetext{
2 "A matriz pode ser considerada como o conjunto de unidades que compõem um mosaico inter-habitat" (METZGER, 2003, p. 58). Segundo Metzger (1999) a permeabilidade da matriz é a resistência imposta pelas unidades da matriz (fragmentos florestais) para a movimentação de espécies animais e vegetais na paisagem juntamente com a densidade de suas ligações.

Estudos Geográficos, Rio Claro, 15(2): p-p, jul./dez. 2017 (ISSN 1678-698X)

http://www.periodicos.rc.biblioteca.unesp.br/index.php/estgeo
} 
espécie e da maneira como ela se locomove na paisagem e interage com seus elementos" (METZGER, 2003, p. 52).

Entretanto, quando uma determinada espécie que está restrita a um fragmento florestal consegue se deslocar de um extremo ao outro em uma paisagem sem ter que sair deste fragmento, diz-se que a paisagem percola ${ }^{3}$. Porém, quando o grau de fragmentação é muito intenso, a conectividade da paisagem passa a não compensar mais os efeitos da fragmentação e deixa de percolar. Este efeito faz com que a matriz se comporte como uma barreira geográfica para o deslocamento das espécies (METZGER, 2003).

As afirmações citadas no parágrafo anterior permitem argumentar sobre a possibilidade da existência de uma extensão mínima de fragmentos florestais que compõem a matriz necessária para manter a conectividade que, consequentemente, proteja a biodiversidade e permita o desenvolvimento agrícola. Estas afirmações também suportam o questionamento sobre a configuração espacial ideal dos fragmentos florestais da paisagem, que permitem a otimização da biodiversidade.

Segundo Metzger (2002; 2003), é possível definir uma proporção crítica a partir da qual a paisagem não permite a percolação das espécies. Trabalhos existentes mostraram que quando o percentual da área ocupada (fragmentos florestais) é menor do que $59,28 \%$ e a conectividade estrutural são pífias, a paisagem não permite o pleno fluxo biológico e sofre significativas mudanças na sua estrutura tais como a diminuição do tamanho médio dos fragmentos e o aumento do grau de isolamento dos mesmos. Abaixo desse valor crítico, a paisagem pode ser caracterizada por ter um alto grau de fragmentação, elevando consideravelmente os riscos de extinção local de espécies, reduzindo a possibilidade de regeneração entre os fragmentos florestais, graças à baixa conectividade biológica (METZGER, 2003).

Desta forma, as estratégias para restaurar a conectividade da paisagem devem ser baseadas na melhoria da rede de corredores (construindo novos ou no aumento do tamanho e a qualidade dos corredores já existentes), restaurando a permeabilidade da matriz da paisagem, através da alteração das características da mesma e/ou aumentando a densidade de pontos de ligação denominados de trampolins ecológicos (stepping-stones). A figura 1 mostra as principais estratégias baseadas no aumento da conectividade da paisagem (METZGER, 2003).

\footnotetext{
3 "Percolação da paisagem ocorre quando a área de floresta cruza a paisagem de ponta a ponta de forma contínua" (METZGER, 2003, p. 53)

Estudos Geográficos, Rio Claro, 15(2): p-p, jul./dez. 2017 (ISSN 1678-698X)

http://www.periodicos.rc.biblioteca.unesp.br/index.php/estgeo
} 
Figura 1: Estratégias de restauração da conectividade da paisagem

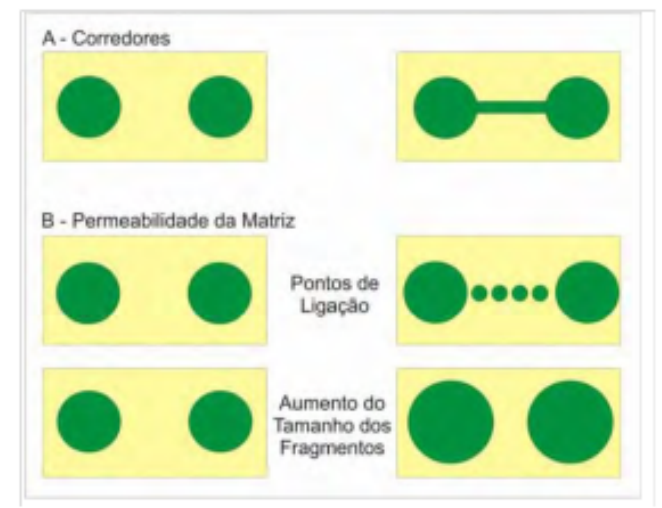

Fonte: Adaptado de Metzger (2003)

A estratégia de restauração da conectividade da paisagem através de corredores é mais utilizada quando os fragmentos são de baixa qualidade e/ou muito pequenos, e a matriz é muito resistente.

Os principais pontos positivos para a utilização desta estratégia devem-se ao fato de que quando associados aos rios, os corredores podem exercer outras funções como, por exemplo, a estabilização das margens dos rios e da depuração das águas. Os pontos negativos deste tipo de estratégia são os elevados custos para implantá-la, pois não há garantia que os corredores facilitem o deslocamento das espécies, além disso, pode facilitar a propagação de perturbações, como o fogo (METZGER, 2003).

A estratégia de trampolins ecológicos deve ser utilizada onde há a predominância de pastagens e/ou onde a estrutura fundiária é composta por pequenas propriedades. Para Metzger (2003), a configuração da paisagem em pequenas propriedades favorece a manutenção de cercas-vivas ou a manutenção de pequenas áreas de preservação em cada propriedade. A grande vantagem desta estratégia está no custo de implantação, pois é mais barata se comparada com os corredores e demanda pouca área para ser implantada. Contudo a sua desvantagem está em não ser efetiva para espécies de interior, sem contar com a existência de poucos estudos que comprovem a sua eficiência na facilitação do fluxo gênico.

A estratégia de restauração da conectividade da paisagem através da alteração das características da matriz deve ser utilizada quando a prática da atividade agropastoril é economicamente viável. A grande vantagem dessa estratégia está na facilidade de ser aceita pelos produtores rurais, na medida em que o aumento da permeabilidade da paisagem não afete no ganho econômico, pois pode ser implantada sem que haja perda de área produtiva. A sua desvantagem está na especificidade de sua utilização, pois só pode ser efetuada para espécies que usam a matriz, não tendo efeito para espécies estritamente de interior (METZGER, 2003).

Outro debate sobre a implantação desta estratégia de restauração ocorreu no período de 1970 a 1990, conhecido pela sigla SLOSS (single large or several Estudos Geográficos, Rio Claro, 15(2): p-p, jul./dez. 2017 (ISSN 1678-698X)

http://www.periodicos.rc.biblioteca.unesp.br/index.php/estgeo 
smmall), isto é, "uma grande ou várias pequenas" (METZGER, 2002). Nestes debates foram discutidas as vantagens e desvantagens de se criar uma grande reserva ou várias reservas pequenas. Para Metzger (2002), cada estratégia possui uma vantagem diferente. A escolha por várias reservas pequenas permite englobar uma maior diversidade de ecossistemas, tipos de vegetação e ambientes que resultariam em uma preservação imediata de um número maior de espécies. Em contrapartida, a existência de uma grande reserva permite a manutenção de um sistema mais íntegro, permitindo a preservação de populações com um tamanho maior, reduzindo assim o risco de extinção (METZGER, 2002; ARAÚJO, 2007). (Figura 2)

Figura 2: Estratégias de restauração ecológica proposta na teoria do aumento da permeabilidade da matriz

\begin{tabular}{|c|c|}
\hline $\mathrm{Pic}$ & Melhor \\
\hline $\begin{array}{c}\text { Ecossistema } \\
\text { Parciaimente } \\
\text { Protegido }\end{array}$ & $\begin{array}{l}\text { Ecossistema } \\
\text { Completamente } \\
\text { Protegido }\end{array}$ \\
\hline $\begin{array}{l}\text { Area } \\
\text { Menor }\end{array}$ & $\begin{array}{l}\text { Área } \\
\text { Maior }\end{array}$ \\
\hline $\begin{array}{c}\text { Area } \\
\text { Fragmentada }\end{array}$ & $\begin{array}{c}\text { Área Nāo } \\
\text { Fragmentada }\end{array}$ \\
\hline $\begin{array}{l}\text { Área } \\
\text { Isolada }\end{array}$ & $\begin{array}{l}\text { Area Menos } \\
\text { Isolada }\end{array}$ \\
\hline
\end{tabular}

Fonte: Adaptado de Primack; Rodrigues (2001); Araújo (2007)

A melhor estratégia a ser adotada para a conservação de áreas florestais no Brasil, salienta Metzger (2002), deve ser a de manter e/ou criar uma grande reserva, já que a escolha dessa estratégia minimiza os riscos de extinção, além de permitir que ocorra a conservação em longo prazo. Entretanto, nenhuma ação de restauração tem por objetivo retomar as condições de uma paisagem não alterada pelo homem, mas sim efetuar uma conciliação de áreas agrícolas produtivas e sustentáveis com áreas de conservação biológica, garantindo a existência de um fluxo gênico mínimo entre os remanescentes florestais viabilizando a manutenção da biodiversidade de uma forma inteligente (MEZTGER, 2003; 2002).

\section{MATERIAL E MÉTODO}

\section{1 Área de Estudo}

O estudo de caso que se materializa neste trabalho foi realizado no Município de Extrema, com área de $243,7 \mathrm{~km}^{2}$, situado no extremo Sul do Estado de Minas Gerais, na bacia do Córrego das Posses (Figura 3). 
O uso da legislação ambiental na restauração...

Figura 3: Localização da área de estudo

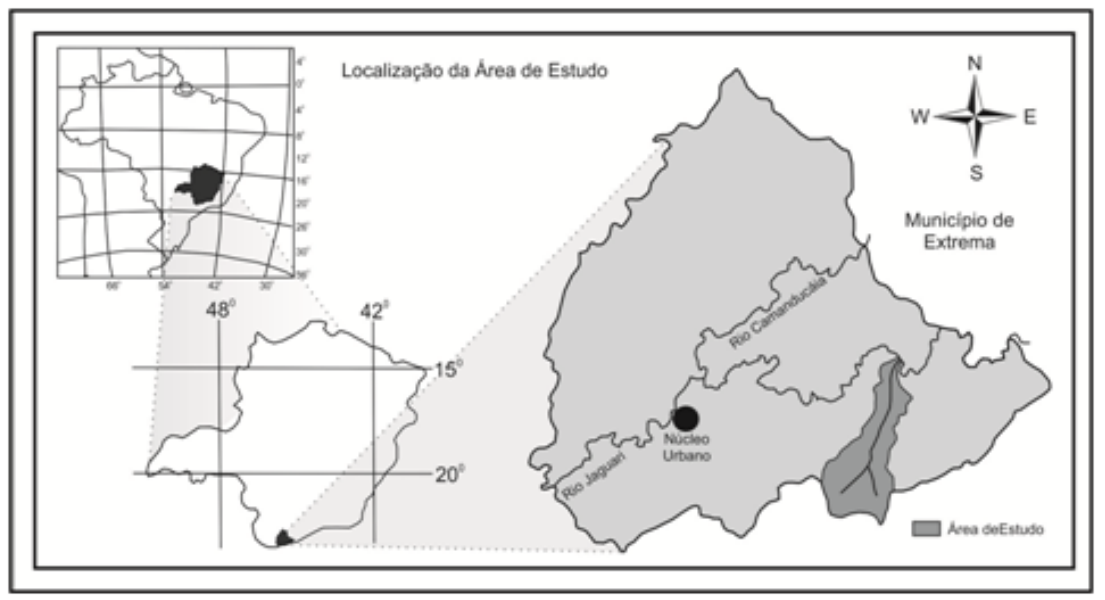

Fonte: IBGE (1979 e 1972)

A seguir, a evolução espaço temporal da área agrícola do município (Figura 4) de Extrema durante o período de 1955 a 2006: 
Figura 4: Evolução do uso da terra do Município de Extrema - MG no período de 1955 a 2006 (em \% da área total do município)

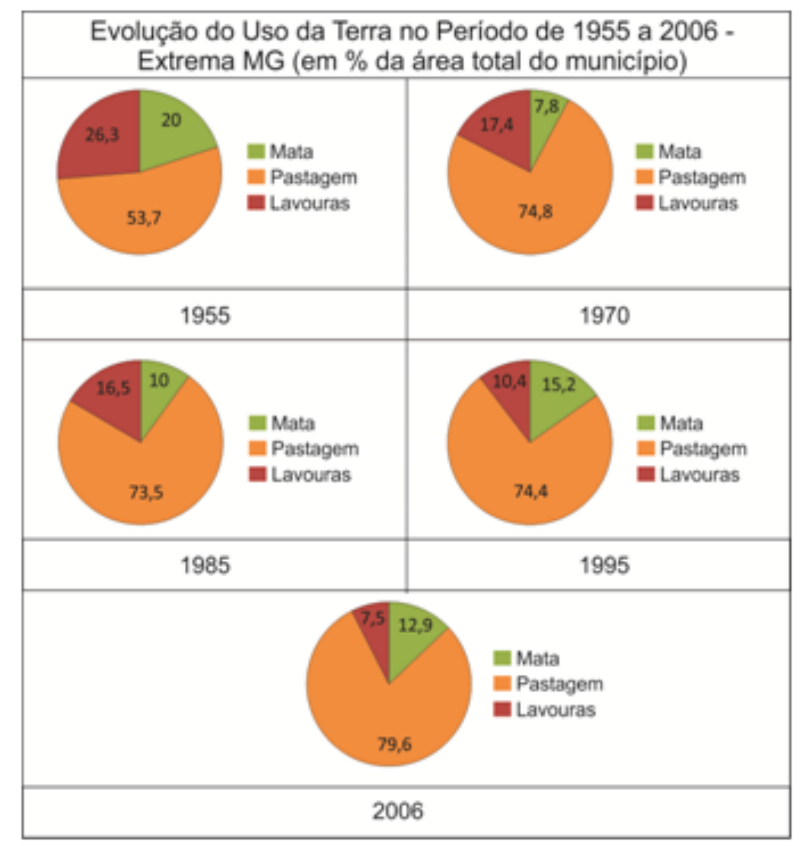

Fonte: IBGE (1959, 1970, 1985, 1995 e 2006)

Nesta figura, além da expressividade das pastagens como uso da terra em cerca de três quartos da área do município, verifica-se a constante diminuição da área das lavouras. As matas apresentam oscilação brusca entre 1955 e 1970 e, a partir daí, variam pouco entre os períodos, mantendo percentuais em torno de $10 \%$ da área total. A oscilação da vegetação natural, nos últimos 20 anos, está relacionada ao aumento populacional expressivo do município de Extrema que apresentou um crescimento de 78,33\% neste período (HOEFFEL et al., 2008).

Segundo estes autores, o desenvolvimento econômico de Extrema, intensificado pela duplicação da Rodovia Fernão Dias, a proximidade com a Região Metropolitana de São Paulo e a especulação imobiliária, acentuaram a expansão urbana e aumentaram a pressão nos ecossistemas florestais.

As porcentagens da área das lavouras temporárias e permanentes podem ser observadas na tabela 1 . 
Tabela 1: Evolução da área cultivada com lavouras permanentes e temporárias do Município de Extrema no período de 1955 a 2006

\begin{tabular}{|c|c|c|c|c|c|}
\hline \multirow{2}{*}{ Culturas } & \multicolumn{5}{|c|}{$\begin{array}{c}\text { Porcentagem da área das lavouras ocupadas por culturas } \\
\text { temporárias e permanentes }\end{array}$} \\
\cline { 2 - 6 } & \multicolumn{5}{|c|}{ Anos } \\
\cline { 2 - 6 } & 1955 & 1970 & 1985 & 1995 & 2006 \\
\hline Arroz & 12,70 & 4,67 & 5,58 & 1,44 & 0,00 \\
\hline Batata Inglesa & 7,70 & 3,25 & 2,67 & 3,44 & 5,30 \\
\hline Café & 31,80 & 5,62 & 2,03 & 5,84 & 2,66 \\
\hline Cana & 0,00 & 0,92 & 1,58 & 2,58 & 2,66 \\
\hline Cebola & 3,63 & 0,39 & 0,61 & 2,97 & 0,00 \\
\hline Cenoura & 0,00 & 0,00 & 0,21 & 0,00 & 0,00 \\
\hline Feijão & 12,37 & 17,40 & 30,48 & 27,94 & 12,62 \\
\hline Laranja & 0,00 & 1,15 & 1,18 & 0,00 & 2,92 \\
\hline Limão & 0,00 & 0,00 & 0,00 & 0,29 & 0,00 \\
\hline Mandioca & 0,00 & 0,00 & 0,21 & 0,57 & 0,00 \\
\hline Milho & 31,80 & 66,60 & 55,12 & 51,96 & 73,04 \\
\hline Pêra & 0,00 & 0,00 & 0,00 & 0,19 & 0,00 \\
\hline Soja & 0,00 & 0,00 & 0,00 & 0,38 & 0,00 \\
\hline Tangerina & 0,00 & 0,00 & 0,00 & 0,29 & 0,00 \\
\hline Uva & 0,00 & 0,00 & 0,33 & 2,11 & 0,80 \\
\hline Total & 100,00 & 100 & 100 & 100 & 100 \\
\hline & & & & & \\
\hline & & & & \\
\hline & & & 0,00 & \\
\hline
\end{tabular}

Fonte: IBGE (1959, 1970, 1985, 1995 e 2006)

Até 1955 a divisão do uso da terra entre as culturas no Município de Extrema obedecia ao esquema tradicional das áreas cafeeiras. O café, como cultura de base econômica, ocupando as maiores extensões, seguido pelo milho para os animais e arroz e feijão para os trabalhadores. Na década de 1970, os dados já mostram o resultado do processo de decadência da cultura cafeeira e o reforço da cultura do milho numa área cuja vocação criatória se define. O feijão amplia sua posição e percebe-se o início de uma pequena diversificação de culturas.

Estudos Geográficos, Rio Claro, 15(2): p-p, jul./dez. 2017 (ISSN 1678-698X)

http://www.periodicos.rc.biblioteca.unesp.br/index.php/estgeo 
Nos momentos seguintes, as posições apenas se consolidam, porém, em 2006 os dados mostram perda sensível de área de feijão em benefício do aumento importante da área do milho. No período de 1980 e 2005 pode-se afirmar, sem dúvida, que a economia e a paisagem de Extrema são dominadas pelas atividades pecuaristas, favorecidas pelas condições ambientais.

O rio Jaguari é o principal curso d'água do município e corta o mesmo em toda a sua extensão, sendo responsável pelo abastecimento de toda a zona urbana. Sua nascente está localizada no munic ípio de Sapucaí Mirim, passando pelo Distrito de Monte Verde e entrando no município pelo bairro do Salto de Cima. Seus principais afluentes são o rio Camanducaia e o ribeirão do Juncal, oriundos dos municípios de Camanducaia e Itapeva e os córregos que nascem na área do município, sendo os principais o ribeirão do Salto de Cima, ribeirão dos Forjos, ribeirão das Furnas, ribeirão Tenentes, ribeirão do Matão e o córrego das Posses (EXTREMA 2005a). Seus interflúvios estão localizados na Serra da Mantiqueira, inserida na Província do Planalto Atlântico, caracterizado por movimentos tectônicos, com marcas de falhas, deslocamento de blocos e falhamentos. O controle estrutural é nítido sobre a morfologia atual, evidenciado pelas extensas linhas de falhas, escarpas e relevos alinhados, ressaltando filões residentes, cristas e sulcos (BRASIL, 1983).

Esta porção do relevo é caracterizada pela alta declividade e amplitudes acima de $300 \mathrm{~m}$ com topos escarpados e vertentes retilíneas. As incisões da drenagem são bem pronunciadas formando vales fechados em V, sobretudo nas áreas onde a erosão regressiva é mais intensa. Nas encostas mais íngremes, há a predominância de cristas simétricas e assimétricas, escarpas e ravinas, com vales encaixados, alinhados ao longo das principais direções de fraturamento. As cristas possuem nítido alinhamento SW-NE, com altitudes que variam de 1450 a $1700 \mathrm{~m}$ (EXTREMA, 2005a).

Quanto à caracterização climática, de acordo com Köppen, o clima predominante na bacia estudada é do tipo Cwb (tropical de altitude) definido como clima quente e úmido com inverno seco, com total de chuvas do mês mais úmido superior a $191 \mathrm{~mm}$ e do mês mais seco inferior a $30 \mathrm{~mm}$, com temperatura média do mês mais quente acima de $21^{\circ}$ e do mês mais frio abaixo de $16^{\circ}$ (EXTREMA, 2005a). A formação geológica do município de Extrema é constituída basicamente de granitos, granitóides, migmatitos diversos, gnaisses dolomíticos, quartziticos e metaconglomerados. As feições geomórficas da área de estudo incluem-se no relevo de degradação em planaltos dissecados, caracterizados por terrenos baixos e planos junto às margens dos rios, constituindo planícies aluviais expressivas, predominando relevos de dissecação fluvial diferencial marcado pelo aprofundamento da drenagem que, nas cabeceiras encontram-se ramificadas e no restante da bacia os rios são mais retilíneos e encaixados, com afluentes na sua maioria de primeira ordem (EXTREMA, 2005a).

Os sistemas de relevo desenvolvidos na região congregam feições geomorfológicas resultantes da conjunção ativa de fatores morfoestruturais e morfoclimáticos que imprimem à paisagem o modelado típico do Domínio Tropical Estudos Geográficos, Rio Claro, 15(2): p-p, jul./dez. 2017 (ISSN 1678—698X)

http://www.periodicos.rc.biblioteca.unesp.br/index.php/estgeo 
Atlântico, desenvolvido sobre rochas cristalinas com espessos mantos de alteração recobertos por floresta tropical úmida (EXTREMA, 2005a) que, na bacia das Posses, é a mais impactada, pois nota-se a presença de pastagem nas áreas íngremes $\mathrm{e}$ nas Áreas de Preservação Permanente.

Segundo Azevedo e Manzatto (2005), a proximidade espacial entre os remanescentes florestais presentes na bacia do córrego das Posses e as variações altitudinais têm sido destacadas como algumas das variáveis ambientais mais importantes da configuração florística da vegetação. Sob esta perspectiva, as espécies de ampla distribuição nos remanescentes presentes na bacia das Posses são as mais representativas devido a sua tolerância e adaptação a uma amplitude topográfica diversificada. Dentre as espécies que se enquadram nestas características podem ser destacadas: o Tamanqueiro (Alchornea triplinervia e Alchornea glandulosa), o Capixingui (Croton floribundus), o Cedro (Cedrela fissilis), o Rabo-de-Macaco (Lonchocarpus campestris), O Açoita-Cavalo (Luehea grandiflora), o Jacarandá-do-Mato (Machaerium villosum), a Canelinha (Nectandra lanceolata), e a Azeitona-do-Mato (Rapanea umbellata).

$\mathrm{Na}$ área observam-se alguns problemas causados pelo uso inadequado do solo, isto é, a substituição da vegetação natural por áreas de pastagem, causando distúrbios na dinâmica das encostas e provocando o voçorocamento das mesmas. Segundo Azevedo e Manzatto (2005), estes impactos ambientais ocorrem em virtude da intrínseca relação da vegetação com as condições topográficas e de relevo.

\subsection{Procedimentos Metodológicos}

Os procedimentos metodológicos utilizados para o desenvolvimento desta pesquisa estão sistematizados na figura 5:

Figura 5: Sequência metodológica empregada

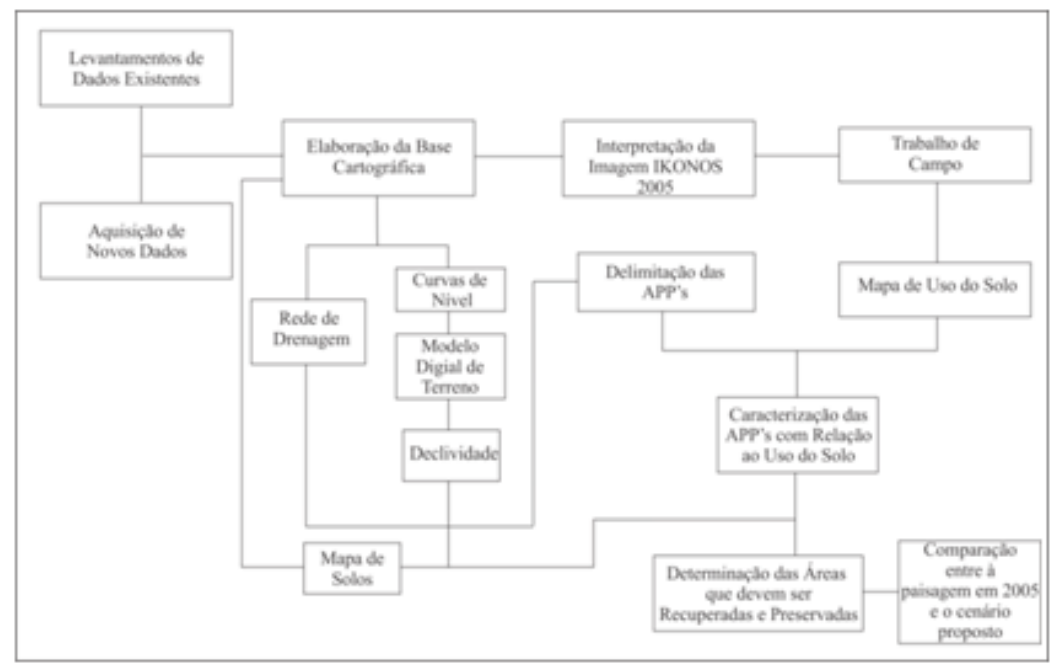

Fonte: $\mathrm{O}$ autor.

Estudos Geográficos, Rio Claro, 15(2): p-p, jul./dez. 2017 (ISSN 1678-698X)

http://www.periodicos.rc.biblioteca.unes p.br/index.php/estgeo 
A elaboração da base cartográfica foi efetuada através da compilação das cartas topográficas Folha Extrema (SF-23-Y-B-IV-3) e Folha Camanducaia (SF-23-YB-N-4) na escala 1:50.000, onde foi selecionada a área de estudo.

A interpretação visual da imagem IKONOS foi efetuada utilizando o sistema hierárquico de classificação de cobertura e uso da terra. A metodologia utilizada neste trabalho foi proposta por Anderson et al. (1976) e classifica os tipos de uso do solo em diferentes níveis de detalhamento, isto é, relaciona cada nível de classificação aos tipos de dados de sensoriamento remoto utilizados Este procedimento fez-se necessário, pois sendo as chaves de interpretação a descrição do conjunto de elementos de interpretação que caracterizam um determinado alvo da superfície da terra o mais preciso e objetivo possível, a precisão da identificação e descrição varia de acordo com o produto de sensoriamento remoto utilizado, pois a resolução espacial influencia na configuração espacial dos objetos, podendo facilitar sua descrição conforme sua aparência no terreno (PEREIRA et al.,1989).

Desta forma, embora a imagem IKONOS propicie um nível de detalhe muito elevado dos tipos de uso do solo, devido à sua resolução espacial ser de $1 \mathrm{~m}$, foi feita uma generalização na interpretação dos dados em função da escala da base cartográfica que é 1:50.000, o que impossibilita a classificação dos tipos de uso do solo em um nível hierárquico de classificação mais detalhado. Assim, a legenda foi definida com base na metodologia desenvolvida por Pereira et al. (1989), estabelecendo as classes de uso do solo com base nas características de cor (tonalidade), forma e textura dos objetos na bacia hidrográfica, conforme mostra a figura 6 :

Figura 6: Chave de classificação dos tipos de uso do solo na Bacia da Posses - Extrema/MG, para o ano de 2005

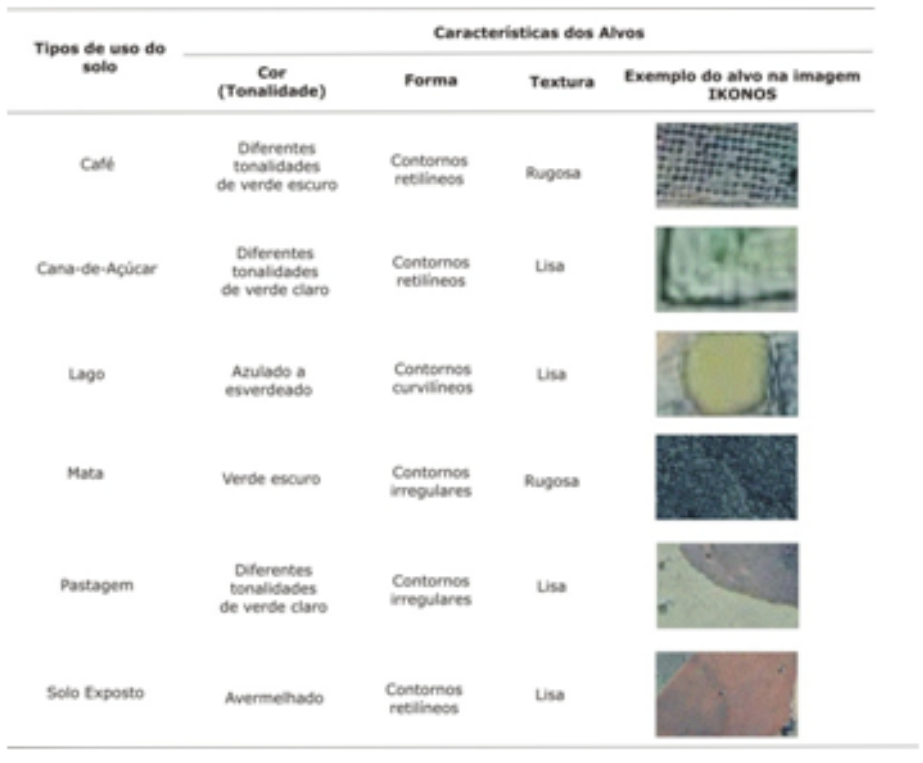

Fonte: $\mathrm{O}$ autor. 
A imagem IKONOS (georreferenciada e corrigida), cedida pela Prefeitura Municipal de Extrema, já disposta no software Auto Cad Map (AUTODESK, 2000), foi classificada visualmente e cada categoria de uso do solo foi vetorizada, em tela em um layer. Além da digitalização dos tipos de uso do solo foram digitalizadas as feições lineares da imagem, isto é, nesta fase foram identificados, vetorizados e os rios e as estradas que compõem a bacia do córrego das Posses. Estas feições, segundo Pereira et al. (1989), podem ser caracterizadas como linhas sinuosas contínuas de trajeto irregular com textura lisa, onde a rede de drenagem é representada em tonalidades azuladas e as estradas possuem tonalidades vermelho esbranquiçadas.

Após esta etapa, cada categoria de uso do solo e as feições lineares (estradas e drenagem), armazenadas em layers diferentes, foram exportadas para o sistema de informação geográfica Idrisi 32 (EASTMAN, 1999), onde foram rasterizados e organizados em uma base de dados com 1 metro de resolução. $O$ produto final desta rotina computacional foi à compilação de oito mapas, representando cada categoria de uso do solo (café, cana-de-açúcar, lagos, mata, pastagem e solo exposto), adicionada às duas feições lineares (drenagem e estradas). Através de operações booleanas, utilizando a função Overlay, contida no módulo Mathematical Operators do Idrisi 32 (EASTMAN, 1999), os layers foram superpostos, gerando no final destas operações, um mapa de uso do solo da bacia do córrego das Posses. Em seguida foram calculados os valores de área em ha, de cada categoria de uso do solo.

O mapa das Áreas de Preservação Permanente (APP) foi embasado no Código Florestal (BRASIL,2012) e nas Resoluções CONAMA (BRAS IL, 1985; 2002a; 2002b; 2006), sendo reconhecidas as seguintes categorias: a) ao longo de rios; b) ao redor das lagoas, lagos ou reservatórios d'água; c) nas nascentes, ainda que intermitentes e nos chamados olhos d'água, seja qual for a sua situação topográfica; d) no topo de morros, montes, montanhas, serras e linhas de cumeada; e) nas encostas ou partes destas, com declividades superiores a $45^{\circ}$, equivalente a $100 \%$ na linha de declive

A sequência para a delimitação das categorias das áreas de preservação permanente foi a seguinte:

a) As Áreas de Preservação Permanente ao longo dos cursos d'água (APP 1) e ao redor dos lagos, lagoas e reservatórios (APP 2), foram delimitadas numa faixa (buffer) de 30 metros às margens do córrego das Posses e seus afluentes; e de 50 metros dos lagos e lagoas da bacia;

b) As Áreas de Preservação Permanente nas nascentes e olhos d'água (APP 3), foram delimitadas numa faixa de 50 metros de distância das nascentes dos rios e olhos d'águas da bacia do córrego das Posses, pela geração de um mapa de distância (buffer) das nascentes;

c) As Áreas de Preservação Permanente nos topos de morros, montes, montanhas, serras e linhas de cumeada (APP 4), foram baseadas nos procedimentos metodológicos descritos por Nascimento et al. (2005) e Soares et al. (2007). Nesta etapa, foram delimitadas as áreas de APP de topos de morro e linhas de cumeada a partir do mapa de curvas de nível em formato digital, com 
equidistância de $20 \mathrm{~m}$, disponibilizado pela Prefeitura Municipal de Extrema. Primeiramente foi gerado um Modelo Digital de Terreno (MDT) com grade regular no sistema de informação geográfica SPRING (INSTITUTO NACIONAL DE PESQUISAS ESPACIAIS, 2001). Em seguida, através da função extração de topos, procedeu-se o mapeamento do terço superior das elevações de acordo com a legislação brasileira. Neste procedimento foram determinados a base e o topo da elevação e em seguida esta rotina computacional delimita automaticamente o terço superior do morro. Após esta etapa, o mapa das APP de topos de morro e linhas de cumeada foi exportado para o sistema de informação geográfica Idrisi 32 (EASTMAN, 1999);

d) As Áreas de Preservação Permanente referente às encostas com declividades superiores a $45^{\circ}$ (APP5), foram elaboradas a partir do mapa de curvas de nível em formato digital, com equidistância de $20 \mathrm{~m}$, disponibilizado pela Prefeitura Municipal de Extrema, que foi exportado para o sistema de informação geográfica Idrisi 32 (EASTMAN, 1999) onde foi rasterizado e organizado em uma base de dados com 1 metro de resolução. O modelo digital de terreno foi elaborado, no módulo SURFACE ANALISYS, através da interpolação do mapa reasterizado das curvas de nível, utilizando a função TIN interpolation. O mapa de declividade bacia das Posses foi compilado no módulo Operações de Contexto do sistema de informação geográfica Idrisi, utilizando a função SURFACE. Após este procedimento, as declividades foram reclassificadas, pela função RECLASS, tendo como produto final um mapa onde são apresentadas as áreas de APP, onde a declividade é maior do que $45^{\circ}$.

Para totalizar as áreas de preservação permanente, foi executada a superposição dos mapas APP 1, APP 2, APP 3, APP 4 e APP 5, obtendo-se um mapa que representa todas as Áreas que deveriam ser de Preservação Permanente (APP Total) da bacia das Posses. Este procedimento foi efetuado através de operações de álgebras de mapas, contida no módulo Mathematical Operators, do Idrisi 32 (EASTMAN, 1999).

A quantificação do uso indevido das áreas de preservação permanente por atividades agrícolas e pecuárias foi elaborada através de operações de tabulação cruzada entre o mapa de uso da terra e o mapa do total das Áreas de Preservação Permanente. As informações obtidas geraram subsídios para mostrar quais são as áreas que não tem uso de acordo com a Legislação Ambiental vigente.

O método utilizado para determinar as áreas prioritárias de conservação, foi baseado em Ranieri (2004). Este método foi utilizado por ser aplicável em situações reais de paisagens fragmentadas, pois respeita o que é estabelecido pela legislação e seus critérios de determinação são baseados em dados de fácil aquisição e de fácil atualização. Este método permite a identificação das áreas prioritárias para a conservação a partir da combinação de critérios que geram um tipo de zoneamento ambiental. A sequência para a delimitação dos critérios propostos por Ranieri (2004) foi a seguinte:

a) Manutenção dos fragmentos existentes: A determinação das áreas para a manutenção dos fragmentos de vegetação foi elaborada através do mapeamento dos fragmentos florestais. Para efetuar este procedimento gerou-se um mapa, no sig 
Idrisi (EASTMAN, 1999), contendo os fragmentos florestais com área igual ou superior a 10 ha. A partir deste mapa, foi compilada uma imagem binária onde foi atribuído o valor 1 para as áreas com vegetação e o valor 0 para as demais áreas;

b) Áreas com Maior suscetibilidade a erosão: O mapa de susceptibilidade à erosão foi elaborado considerando a declividade e os tipos de solos. O procedimento metodológico para a compilação do mapa de declividade está descrito acima, sendo que para esta etapa as declividades foram reclassificadas, pela função RECLASS, adotando as seguintes classes: $0-2 \%, 2-5 \%, 5-10 \%, 10-20 \%$ e $>20 \%$. O mapeamento das unidades pedológicas foi efetuado seguindo os procedimentos metodológicos encontrados em Jesus (2004). Esta técnica, delimita os tipos de solos baseando-se nas características fisiográficas, hipsométricas, e de declividade da área de estudo. Associado a este procedimento metodológico, foram coletadas amostras de solo no trabalho de campo. As amostras foram levadas ao Laboratório de Física do Solo da UFSCar, localizado na cidade de Araras - SP, onde os parâmetros físico-químicos do solo (fertilidade aparente, profundidade efetiva, drenagem interna e textura) foram determinados. A partir destes parâmetros e com o auxílio das cartas topográficas Extrema e Camanducaia, as unidades pedológicas foram mapeadas. O mapa de suscetibilidade à erosão foi elaborado através de operações de tabulação cruzada entre o mapa de solos e o mapa de declividade (Figura 7).

Figura 7: Matriz de decisão para a determinação de suscetibilidade à erosão

\begin{tabular}{|c|c|c|c|c|c|}
\hline \multirow{2}{*}{ Tipos de Solos } & \multicolumn{5}{|c|}{ Declividade } \\
\cline { 2 - 6 } & $0-2 \%$ & $2-5 \%$ & $5-10 \%$ & $10-20 \%$ & $>20 \%$ \\
\hline Latossolo Roxo & $\mathbf{B}$ & $\mathbf{B}$ & $\mathbf{B}$ & MA & MA \\
\hline Latossolo Vermelho Escuro & $\mathbf{B}$ & $\mathbf{B}$ & $\mathbf{B}$ & MA & MA \\
\hline Latossolo Vermelho Amarelo & $\mathbf{B}$ & $\mathbf{B}$ & $\mathbf{M}$ & MA & MA \\
\hline Argissolo Vermelho Amarelo & $\mathbf{M}$ & $\mathbf{A}$ & $\mathbf{A}$ & MA & MA \\
\hline Terra Roxa Estruturada & $\mathbf{B}$ & $\mathbf{B}$ & $\mathbf{M}$ & MA & MA \\
\hline Neossolo Litólito & $\mathbf{M}$ & $\mathbf{M}$ & $\mathbf{A}$ & MA & MA \\
\hline Areia Quartizosa & M & A & MA & MA & MA \\
\hline Hidromórfico & NA & NA & NA & NA & NA \\
\hline
\end{tabular}

$B=$ baixa suscetibilidade; $M=$ média suscetibilidade; $A=$ alta suscetibilidade; $M A=$ muito alta suscetibilidade e NA não se aplica.

Fonte: Ranieri (2004) 
A partir deste mapa, foi criada uma imagem binária onde foi atribuído o valor 1 para as áreas de alta e muito alta suscetibilidade a erosão e o valor 0 para as demais áreas. Esta operação foi efetuada através da função RECLASS do SIG Idrisi 32 ;

c) Aumento da área dos fragmentos existentes: O aumento da área dos fragmentos florestais foi delimitado, numa faixa de $60 \mathrm{~m}$ ao redor dos fragmentos florestais localizados fora da área de APP. A partir deste mapa, gerou-se uma imagem binária onde foi atribuído o valor 1 para as áreas de expansão da vegetação e o valor 0 para as demais áreas;

d) Alargamento das faixas de vegetação ao longo dos corpos d'água: O alargamento das faixas de vegetação ao longo dos corpos d'água foi delimitado, numa faixa de $60 \mathrm{~m}$ além das Áreas de Preservação. Para efetuar esta conduta metodológica, foi compilado um mapa de distância (buffer) dos fragmentos de vegetação. A partir deste mapa, gerou-se uma imagem binária onde foi atribuído o valor 1 para as áreas de expansão a vegetação ao longo dos corpos d'água e o valor 0 para as demais áreas;

e) Proteção das cabeceiras das bacias: Nesta fase foram mapeadas as bacias sem canais tributários, isto é, de primeira ordem, pela classificação de STRAHLER (STRAHLER, 1952; CHRISTOFOLETTI,1980; STEVAUX e LATRUBESSE, 2017). Estas bacias foram identificadas nas cartas topográficas Extrema e Camanducaia e vetorizadas. O mapa de bacias de primeira ordem foi exportado para o sistema de informação geográfica Idrisi 32 (EASTMAN, 1999), Às bacias de primeira ordem foi dado o valor 1 , e às demais áreas foi dado o valor 0 ;

f) Redução das distâncias entre os fragmentos: $O$ limite máximo que pode ser considerado para evitar o isolamento dos fragmentos florestais é de $1000 \mathrm{~m}$. A condução desta tarefa se baseou na compilação de um mapa de distância (buffer) superiores a $1000 \mathrm{~m}$ dos fragmentos. A imagem binária, gerada a partir deste mapa, foi atribuído o valor 1 para as áreas com distâncias superiores a 1000m e o valor 0 para as demais áreas.

Para Ranieri (2004), todos os critérios têm importância equivalente, isto é, todos possuem o mesmo peso para a locação das áreas prioritárias de Reserva Legal. Segundo o mesmo autor, a sobreposição de dois critérios já é suficiente para considerar esta área como prioritária, entretanto quanto maior for a quantidade de fatores sobrepostos, maior será a sua prioridade de locação. Porém, em virtude da localização geográfica da área de estudo e da escala de abordagem adotada, foram consideradas relevantes para determinar as áreas prioritárias de conservação florestal em que houve a sobreposição de pelo menos três critérios. O produto final destas operações foi um mapa que mostra as áreas prioritárias para a locação das áreas de restauração florestal na bacia do córrego das Posses que, juntamente com o mapeamento das áreas de APP, permitiu desenhar um cenário ideal da vegetação natural da área estudada.

O procedimento metodológico para efetuar a comparação entre as paisagens no ano de 2005 e o cenário proposto foi o mesmo foi efetuada através de métricas de paisagem. Segundo Ranieri (2004), as oito métricas mais relevantes para a comparação de paisagens são: 
a) Número de fragmentos florestais;

b) Área do conjunto de fragmentos florestais;

c) Área média dos fragmentos florestais;

d) Porcentagem da área ocupada por fragmentos florestais;

e) Número de áreas centrais dos fragmentos florestais;

f) Área central total dos fragmentos florestais;

g) Área central média dos fragmentos florestais;

h) Distância média do vizinho mais próximo.

Os mapas de fragmentos florestais de 2005 e o mapa de vegetação ideal foram exportados do SIG Idrisi para o software Fragstats (McGARRIGAL; MARKS, 1995), onde as métricas de ecologia de paisagem, mencionadas foram calculadas e posteriormente comparadas, tendo como objetivo final, a identificação das alterações estruturais da paisagem.

\section{RESULTADOS DE DISCUSSÃO}

De acordo com o que estabelece o Código Florestal, 38,19\% da área da bacia hidrográfica do córrego das Posses são considerados Área de Preservação Permanente (Figura 8). Embora a porcentagem de ocorrência de vegetação nativa da bacia do córrego das Posses esteja acima da média das bacias hidrográficas mineiras, as Áreas de Preservação Permanente encontram-se bem degradas, ou seja, apenas 12,66\% (56,41 ha), da área de APP estão cobertos com vegetação nativa, como previsto pelo Código Florestal (Tabela 2). 
O uso da legislação ambiental na restauração...

Figura 8: Mapa dos locais onde as APP's, da bacia do córrego das Posses, devem ser recuperadas

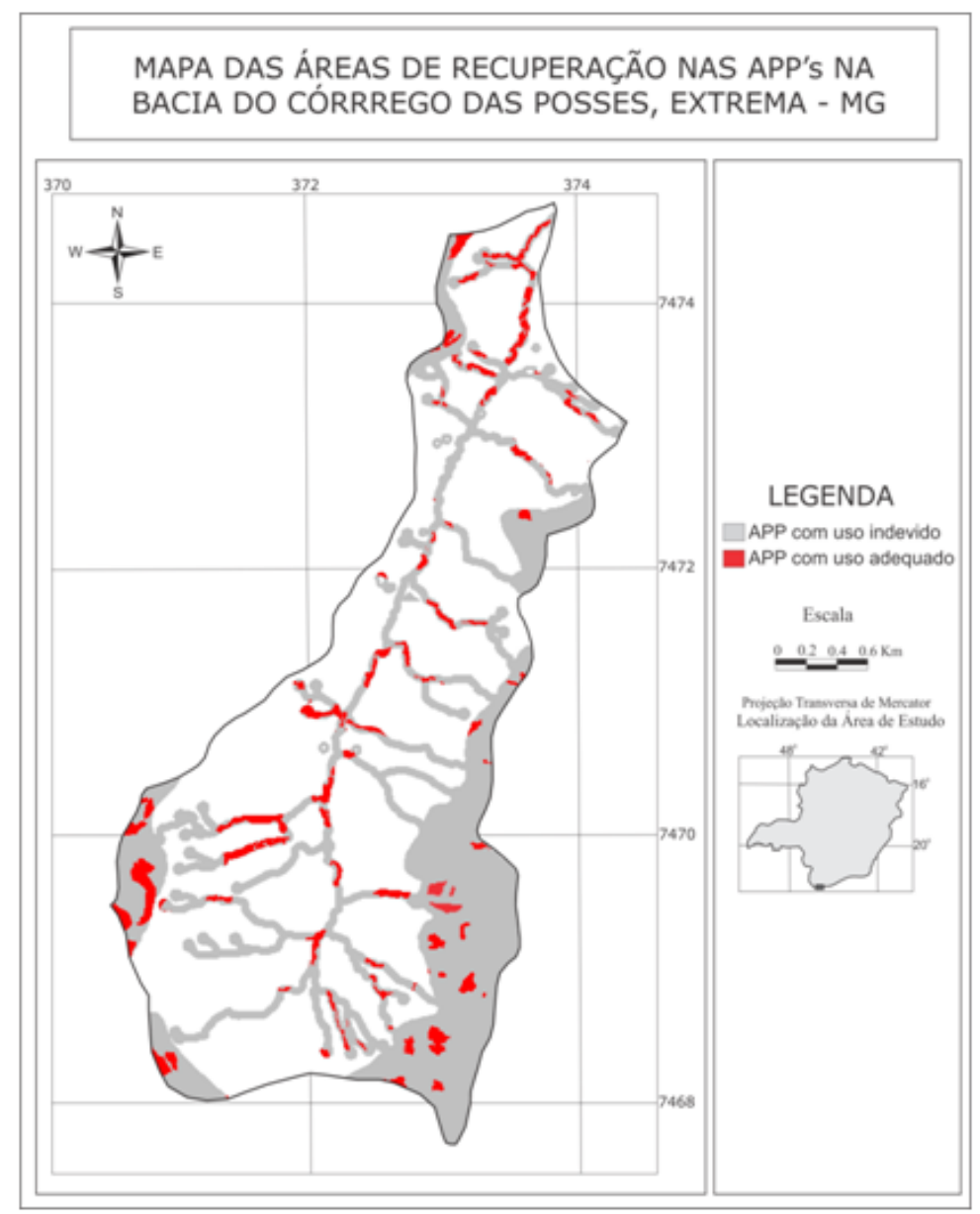

Fonte: $\mathrm{O}$ autor.

Na tabela 2, verifica-se que 385,01 ha $(86,37 \%)$, da Área de Preservação Permanente estão ocupados por pastagens e menos de um por cento está ocupado por estradas, solo exposto e cultivos agrícolas, representados por cana-de-açúcar e café. 
O uso da legislação ambiental na restauração...

Tabela 2: Uso do solo nas APP's da bacia do córrego das Posses

\begin{tabular}{ccccc}
\hline \multirow{2}{*}{$\begin{array}{c}\text { Uso } \\
\text { do solo }\end{array}$} & \multicolumn{2}{c}{ Uso do solo nas APP's } & \multicolumn{2}{c}{ Uso do solo fora das APP's } \\
\cline { 2 - 5 } & Área (ha) & $\%$ & Área (ha) & $\%$ \\
\hline Pastagem & 388,37 & 86,49 & 627,30 & 83,31 \\
Mata & 56,41 & 12,56 & 95,56 & 12,68 \\
Solo Exposto & 1,61 & 0,35 & 18,74 & 2,48 \\
Estrada & 2,4 & 0,53 & 8,05 & 1,06 \\
Cana & 0,3 & 0,066 & 1,59 & 0,21 \\
Café & 0,02 & 0,004 & 1,56 & 0,26 \\
Total & 449,11 & 100 & 752,80 & 100 \\
\hline
\end{tabular}

Fonte: O autor

Na figura 8, percebe-se, também, que se implantadas, haveria coalescência natural entre as APP's formando corredores ecológicos ao longo da bacia hidrográfica do córrego das posses. O que seria muito importante pela facilitação da movimentação de agentes de dispersão de sementes, proporcionando a recuperação da vegetação nativa. Resultados parecidos foram encontrados por Ribeiro et al. (2005), que encontraram padrões paisagísticos parecidos muito semelhantes na bacia hidrográfica do córrego Paraíso, situado no município de Viçosa, MG.

O mapeamento das APP's por alínea do Código Florestal e suas métricas podem ser observadas na tabela 3 e na figura 9 a seguir.

Tabela 3: Categorias de APP's da bacia do córrego das Posses.

\begin{tabular}{|c|c|c|c|c|c|c|c|c|c|c|}
\hline \multicolumn{11}{|c|}{$\begin{array}{c}\text { Áreas de Preservação Permanente } \\
\text { Lei № 12.651, DE } 25 \text { DE M AIO DE } 2012\end{array}$} \\
\hline \multirow[t]{2}{*}{$\begin{array}{l}\text { Uso do } \\
\text { solo }\end{array}$} & \multicolumn{2}{|c|}{$\begin{array}{c}\text { Rios } \\
\text { (APP 1) }\end{array}$} & \multicolumn{2}{|c|}{$\begin{array}{l}\text { Lagos } \\
\text { (APP 2) }\end{array}$} & \multicolumn{2}{|c|}{$\begin{array}{l}\text { Nascentes } \\
\text { (APP 3) }\end{array}$} & \multicolumn{2}{|c|}{$\begin{array}{l}\text { Topo de } \\
\text { Morros } \\
\text { (APP 4) }\end{array}$} & \multicolumn{2}{|c|}{$\begin{array}{l}\text { Declividade } \\
>45^{\circ} \\
\text { (APP 5) }\end{array}$} \\
\hline & Área & $\%$ & Área & $\%$ & Área & $\%$ & Área & $\%$ & Área & $\%$ \\
\hline Pastagem & $\begin{array}{c}157,205 \\
36,315\end{array}$ & $\begin{array}{l}79,53 \\
18,51\end{array}$ & $\begin{array}{l}7,68 \\
0,29\end{array}$ & 91,31 & 40,152 & $\begin{array}{l}92,77 \\
718\end{array}$ & 182,473 & $\begin{array}{c}91,75 \\
824\end{array}$ & $\begin{array}{l}0,86 \\
028\end{array}$ & $\begin{array}{l}75,44 \\
24,56\end{array}$ \\
\hline $\begin{array}{l}\text { Solo } \\
\text { Exposto }\end{array}$ & 1,48 & 0,75 & 0,13 & 1,55 & 0,100 & 0 & 10,411 & 0 & 0 & 0 \\
\hline Cana & 0,17 & 0,09 & 0,13 & 1,55 & 0 & 0 & 0 & 0 & 0 & 0 \\
\hline Café & 0,02 & 0,01 & 0 & 0 & 0 & 0 & 0 & 0 & 0 & 0 \\
\hline Estrada & 2,2 & 1,11 & 0,18 & 2,15 & 0,02 & 0,05 & 0 & 0 & 0 & 0 \\
\hline Total & 197,39 & 100 & 8,41 & 100 & 43,28 & 100 & 198,89 & 100 & 1,14 & 100 \\
\hline
\end{tabular}


Figura 9: Mapas das Categorias de APP's da bacia do córrego das Posses

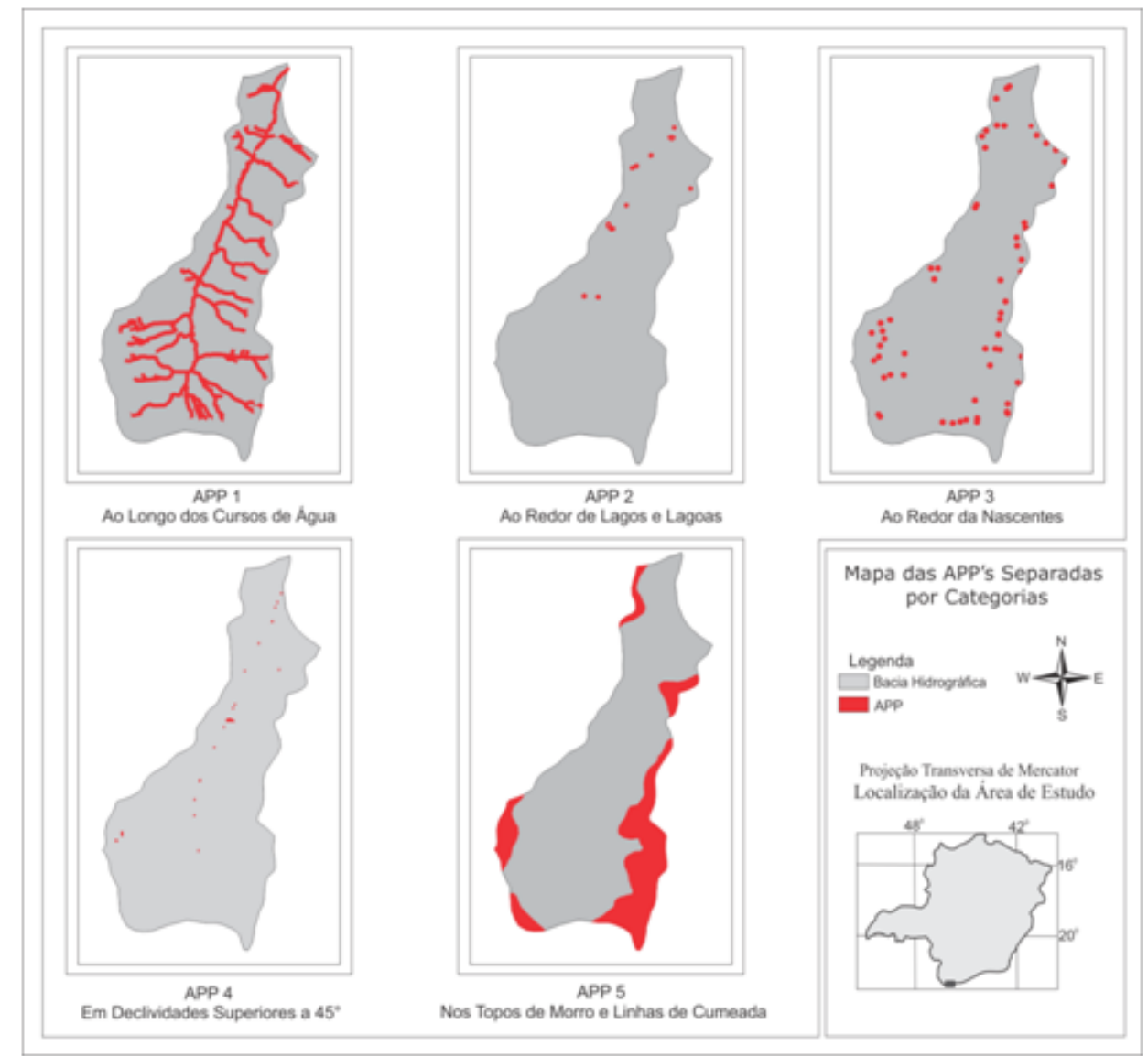

Fonte: $\mathrm{O}$ autor

A quantificação do uso do solo conflitante, das cinco categorias de APP, mostra que apenas nas APP's com declividade maior do que $45^{\circ}$, o percentual de matas atinge mais que $20 \%(24,56 \%)$ da área que deveria ser florestada. Em nenhuma das outras situações, o percentual de matas atinge mais que $20 \%$ da área que deveria ser florestada.

Apesar do cultivo agrícola (cana-de-açúcar e café), ocupar apenas 0,1\% das áreas de APP ao longo dos córregos e 1,55\% ao longo dos lagos este tipo de uso conflitante pode provocar contaminação dos mesmos, pela lixiviação de insumos agrícolas, ou provocar o assoreamento dos rios e lagos devido a existência de solo exposto que ocupa um pouco mais que $3 \%$ da área de APP, nestas categorias.

As estradas também contribuem para a degradação das áreas de APP. Este uso é mais proeminente na categoria de APP ao redor dos lagos em que $3,56 \%$ da área são ocupados por estradas.

O principal problema de invasão de áreas que deveriam ser de preservação permanente na bacia das Posses ocorre pelo avanço das pastagens, que ocupam $92,77 \%$ das áreas de nascentes, $91,75 \%$ das áreas de topos de morro, $85,55 \%$ das áreas ao redor dos lagos, $79,53 \%$ das áreas marginal dos rios e $75,44 \%$ nas áreas onde a declividade é superior a $45 \%$.

Estudos Geográficos, Rio Claro, 15(2): p-p, jul./dez. 2017 (ISSN 1678-698X)

http://www.periodicos.rc.biblioteca.unesp.br/index.php/estgeo 
Segundo Pinto (2005), este tipo de uso pode ser considerado um grande agente de degradação, devido ao impacto negativo das pastagens mal manejadas sobre a regeneração da vegetação natural, a compactação do solo, o voçoracamento, o deslizamento das encostas e principalmente a contaminação das nascentes.

Estes resultados mostraram que a bacia do córrego das Posses está em um estágio de degradação muito elevado, havendo a necessidade de efetuar a restauração ecológica da paisagem através do reflorestamento das áreas de APP's.

Embora já se saiba que as APP's e as RL's são reconhecidas por diversos setores da sociedade como dispositivos legais que possuem um relevante papel no resgate e na preservação da biodiversidade, assim como na proteção do solo e da água, a ação meramente coerciva e repressiva do Estado tem se mostrado insuficiente para garantir, de forma mais generalizada, o cumprimento da legislação ambiental pelos proprietários rurais (RAMOS FILHO, 2007). Na bacia do córrego das Posses, que apresenta um estágio de degradação elevado nestas áreas, mesmo existindo penalidades impostas pela Lei 14.309 de 19 de junho 2002 (MINAS GERAIS, 2002), que prevê no seu artigo 54 uma multa de $R \$ 1.000$ reais para cada hectare de vegetação desmatado ou danificado, a situação de degradação continua grave.

Segundo Kageyama et al. (2007), a grande dificuldade de se efetuar a recuperação e a restauração das áreas de APP's e de RL's está na relação entre o modo de produção rural e a conservação ambiental pois, para os proprietários rurais, a conservação e a recuperação destas áreas são vistas como barreiras econômica e cultural, sendo consideradas como um dispositivo legal punitivo e não um dispositivo legal de ordenamento territorial.

O trabalho efetuado por Joels (2002) no Distrito Federal mostrou que 35\% dos proprietários rurais convencionais ${ }^{4}$ manifestaram-se contra as normativas de comando e controle impostas pelo Código Florestal. Entretanto, quando esta variável foi projetada somente para os produtores rurais que têm a atividade agropecuária como única fonte de renda, como ocorre na bacia das Posses, a porcentagem de propriedades que não possuem que estão irregulares aumenta para $76 \%$.

Para Ramos Filho (2007), a quase inexistência de incentivos econômicos para a recomposição e conservação destas áreas também é vista como uma barreira econômica. Segundo Ranieri (2004); A hrens (2005) a única iniciativa governamental brasileira para estimular os proprietários rurais a conservar as áreas de APP foi a isenção do imposto territorial rural sobre essas áreas. Contudo este dispositivo normativo não é aplicado em pequenas glebas rurais ${ }^{5}$ (BRASIL, 2007) e na bacia do

\footnotetext{
${ }^{4}$ Segundo Joels (2002) os proprietários rurais convencionais são os produtores que utilizam o modelo de produção embasado no crescimento e na prosperidade, voltada à economia de mercado livre, ao direito de propriedade e a visão de que a natureza tem que ser dominada e tornada útil.

${ }^{5}$ São consideras pequenas glebas rurais as propriedades com área inferior a: "a) 100 ha, se localizado em município compreendido na Amazônia Ocidental ou no Pantanal mato-grossense e sul-mato-grossense; b) 50 ha, se localizado em município compreendido no Polígono das Secas ou na Amazônia Oriental; e c) 30 ha, localizado em qualquer outro município" (BRASIL, 2007).
} 
córrego das Posses, esta iniciativa legal só pode ser adotada em propriedades com mais de 30 ha.

O valor do desconto do ITR depende muito do tamanho da propriedade e de que proporção de Áreas de Preservação Permanente cada propriedade possui. Entretanto, as propriedades que regularizarem os dispositivos normativos legais referentes às estas áreas, terão um considerável desconto no valor do imposto territorial rural.

Como já observado, este incentivo legal de desconto do ITR só beneficia as propriedades rurais com mais de 30 ha. Os pequenos proprietários, por sua vez, são contemplados pelos incentivos especiais contidos na Resolução CONAMA 369 de 28 de março de 2006 (BRASIL, 2006) e na Lei 14.309 de 19 de junho de 2002 (MINAS GERAIS, 2002). No Estado de Minas Gerais este tipo de fomento é realizado pelo Instituto Estadual de Florestas (IEF) através do repasse de insumos (mudas, mourões, arame, grampo e adubo) e assistência técnica para o plantio e manutenção, permitindo a recuperação da área degradada. Desta forma, o proprietário rural interessado em participar deste programa deve ir até o escritório do Instituto Estadual de Florestas, no seu município, realizar um cadastro, e aguardar a visita técnica do funcionário desta instituição ${ }^{6}$.

Contudo, estes dispositivos legais ainda são incipientes para promover a restauração das áreas de APP, assim como também são insuficientes para fornecer uma estabilidade econômica a estas glebas rurais, já que nas pequenas propriedades, as barreiras econômicas tendem a se agravar devido à pouca disponibilidade de área para a prod ução e sobrevivência da família (RANIERI, 2004;

RAMOS FILHO, 2007).

Ranieri (2004) salienta que as principais estratégias de recuperação das Áreas de Preservação Permanente devem ser adotadas em parceria, isto é, os instrumentos de comando e controle existentes na legislação devem atuar em conjunto com instrumentos econômicos que resultou na conservação e na preservação destas áreas. Kageyama et al. (2007) salientam que antes de implementar qualquer estratégia de recuperação, se deve levar em consideração que proporção as APP's representam nas propriedades rurais, isto é, qual é a extensão destes dispositivos legais nas glebas rurais.

Segundo estes autores, esta consideração é relevante, pois é a partir deste ponto que as estratégias de recuperação e restauração das APP's devem ser fundamentadas. Uma possibilidade para tentar diminuir os conflitos econômicos dos instrumentos legais é o "regime de condomínio entre mais de uma propriedade, respeitando o percentual legal em relação a cada imóvel" (BRASIL, 2000). Este sistema possibilita que uma propriedade rural que não tenha área de vegetação nativa suficiente para atingir o percentual mínimo para compor a Reserva Legal prevista pela legislação, possa recuperar este déficit em outras propriedades desde que estejam localizadas na mesma bacia e sejam do mesmo ecossistema.

\footnotetext{
${ }^{6}$ Informação dada pelo Engenheiro Florestal Carlos Jose Andrade Silveira Analista Ambiental do Instituto Estadual de Florestas de Minas Gerais, consultada por escrito pelo autor.
} 
Para Ranieri (2004), o mecanismo de locação representa um estímulo à recuperação e à conservação da vegetação nativa, pois o proprietário rural que possuir áreas naturais excedentes pode negociar com outros proprietários garantindo um rendimento adicional sobre a sua área de mata.

Entretanto, salienta Joels (2002), que o mecanismo de condômino florestal é considerado, por algumas entidades ambientalistas, como inadequado, pois deixa margem a uma interpretação dúbia da legislação, concebendo a existência de vastas áreas agrícolas como as monoculturas de soja ou de a cana-de-açúcar, características da agricultura convencional, ao invés de incentivar a alocação da Reserva Legal como elemento chave para a diversificação da paisagem rural e para o desenvolvimento de uma agricultura sustentável.

Para a realidade encontrada na área de estudo, somente o regime de condomínio florestal não é suficiente para garantir a restauração total da bacia das Posses, pois este mecanismo de compensação somente pode ser implantado para a instituição da Reserva Legal, não podendo ser expandido, segundo a legislação ambiental, para as Áreas de Preservação Permanente.

Face a este impedimento, Kageyama et al. (2007) salientam que o pagamento por serviço ambiental (PSA) seria a estratégia mais apropriada, já que suplementa o regime de compensação florestal, possibilitando que os proprietários de terras efetuem a manutenção das áreas de vegetação natural dentro das áreas de APP's e de RL's, já que recebem uma compensação financeira por este serviço.

Estudos realizados por Ramos Filho (2007) mostram que os PSA's possuem boa viabilidade econômica trazendo vários benefícios ambientais, pois cumprem significativamente a biodiversidade, principalmente quando comparados à situação original de degradação encontrado atualmente em áreas de APP.

Assim, as soluções dos usos conflitantes das APP's, na bacia do córrego das Posses, estão fundamentadas em estratégias de gestão de áreas protegidas que incorporam programas de manejo que agrupam várias atividades, que efetuam a contemporização da situação existente, estabelecendo procedimentos que minimizem os impactos sobre a paisagem.

Por fim, solucionados os problemas econômicos, a última estratégia de recomposição da paisagem é a alocação das áreas prioritárias de restauração florestal; levando em consideração conectividade dos fragmentos florestais, a prefeitura do Município de Extrema, por meio do Projeto-Lei 2001/05 denominado Projeto Conservador das Águas propõe medidas para que seja feita a recomposição da cobertura vegetal nas áreas de APP do munic ípio (EXTREMA, 2005b).

Além disso, esta lei proporciona o cumprimento do Plano Diretor, Lei $N^{\circ} 1574$ de 15 de janeiro, de 2001 (EXTREMA, 2001) que, no capítulo III, artigo 5, inciso IV, estabelece uma Zona de Preservação Ambiental (ZPA) correspondente:

As áreas da Serra do Lobo (Serra da Mantiqueira), com cobertura vegetal original pertencente à Reserva da Biosfera da Mata Atlântica, de grande beleza cênica e importante para a preservação de mananciais e da qualidade ambiental do município (EXTREMA, 2001, p. 03). 
No inciso $\mathrm{N}$, parágrafos $6^{\circ}$ e $7^{\circ}$ desta Lei, o Município deverá proceder ao tombamento das áreas situadas na serra da Mantiqueira como patrimônio natural, impedindo qualquer tipo de uso que viole a sua preservação, estabelecendo assim diretrizes para a ocupação da ZPA, respeitando legislação Estadual e Federal, inclusive a APA FERNÃO DIAS. O mapeamento das APP's na base cartográfica das propriedades existentes na bacia do córrego das Posses pode ser observado no mapa 12 e as métricas extraídas deste mapeamento aparecem na figura 7 .

Na tentativa de solucionar este impasse, a aplicação do método proposto por Ranieri (2004) pode suplementar as diretrizes do PSA propostas pela Prefeitura Municipal de Extrema, pois delimita as áreas prioritárias para a alocação de áreas de restauração florestal, através de critérios que consideram a proteção dos componentes biológicos com a conservação de solos e dos recursos hídricos (Figura 10).

Figura 10: Mapa das áreas prioritárias para a restauração florestal além das APPs

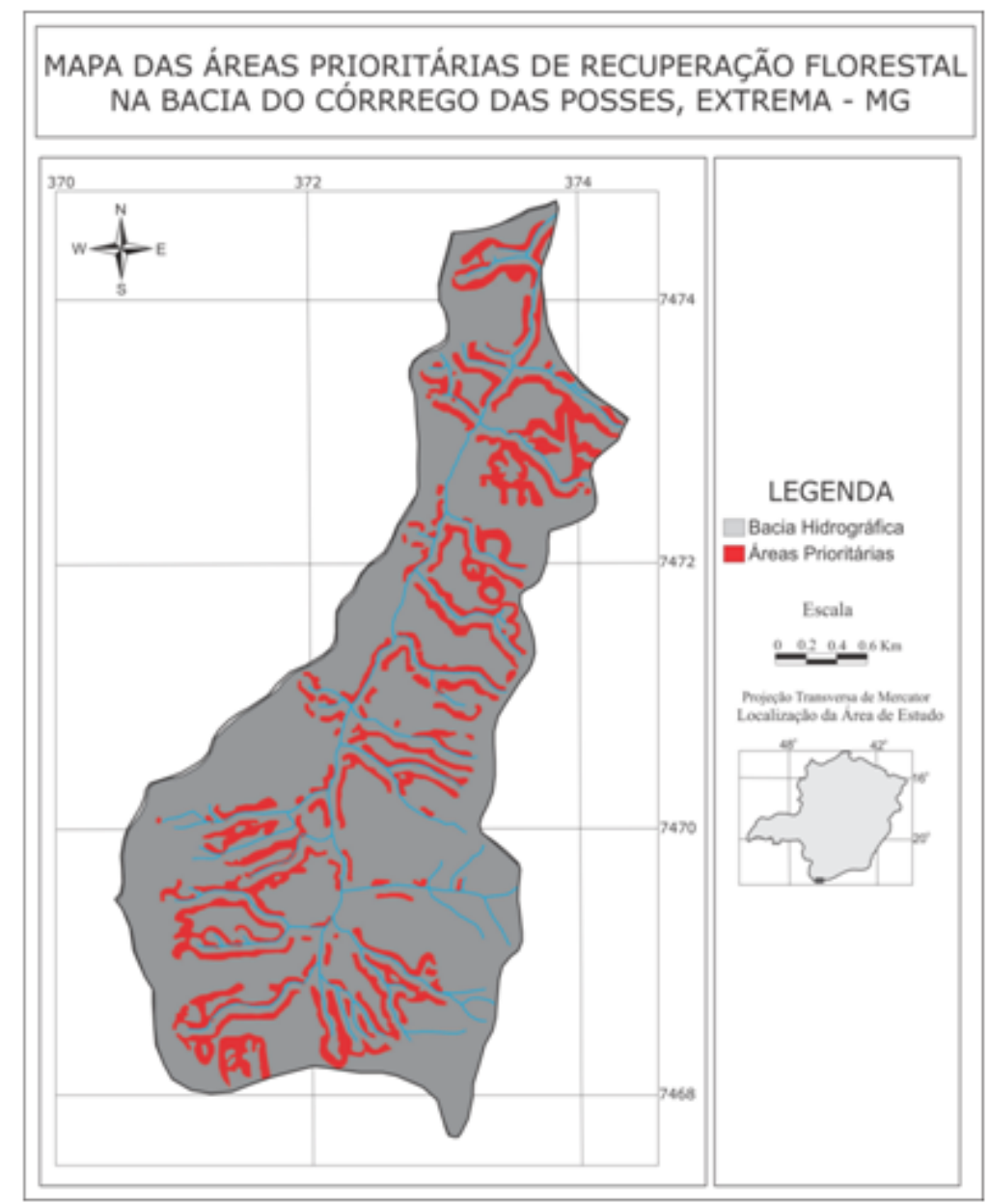

Fonte: O autor 
A figura 10, identifica as áreas prioritárias para a alocação da recomposição florestal, além das áreas de APP. Estas áreas representam 14,96\% (179,86 ha) da bacia do córrego das Posses. A determinação das áreas prioritárias permite identificar o quanto a estrutura da paisagem pode mudar $e$, assim, fornecer importantes subsídios para a tomada de decisões sobre a ocupação do território. As comparações entre a paisagem atual e a paisagem com as áreas de APP recompostas e as áreas prioritárias para a restauração florestal podem ser observadas na tabela 4.

Tabela 4: Comparação das métricas de ecologia de paisagem na bacia do córrego das Posses entre a paisagem atual e a paisagem com as áreas florestais recuperadas

\begin{tabular}{lcc}
\hline \multicolumn{1}{c}{ Métricas da Paisagem } & $\begin{array}{c}\text { Cenário } \\
\text { Em 2005 }\end{array}$ & $\begin{array}{c}\text { Cenário com a } \\
\text { vegetação florestal } \\
\text { recomposta }\end{array}$ \\
\hline Número de fragmentos florestais & 110 & 25 \\
Área do conjunto de fragmentos florestais (ha) & 151,97 & 691,11 \\
Área média dos fragmentos florestais (ha) & 1,28 & 136,12 \\
Porcentagem da área ocupada por fragmentos & 11,74 & 57,84 \\
florestais & 109 & 8 \\
Número de áreas centrais dos fragmentos florestais & 110,74 & 550,19 \\
Área central total dos fragmentos florestais (ha) & 1,006 & 68,27 \\
Área central média dos fragmentos florestais (ha) & 71,52 & 58,5 \\
Distância média do vizinho mais próximo (m) & & \\
\hline
\end{tabular}

Fonte: $\mathrm{O}$ autor.

No cenário em 2005, os remanescentes florestais estão distribuídos por toda bacia, totalizando 151,97 ha $(12,64 \%)$, a paisagem as áreas florestais recuperadas totalizariam 691,11 há $(57,84 \%)$ (Figura 11).

Em 2005, o número de fragmentos florestais é de 110. No cenário proposto para efetuar a recuperação da paisagem o número de fragmentos é de apenas 25 . Neste contexto a área média destes fragmentos florestais aumenta para 691,11 ha enquanto que em 2005 registra-se a média de 151,97 ha. 
Figura 11: Mapa da paisagem restaurada

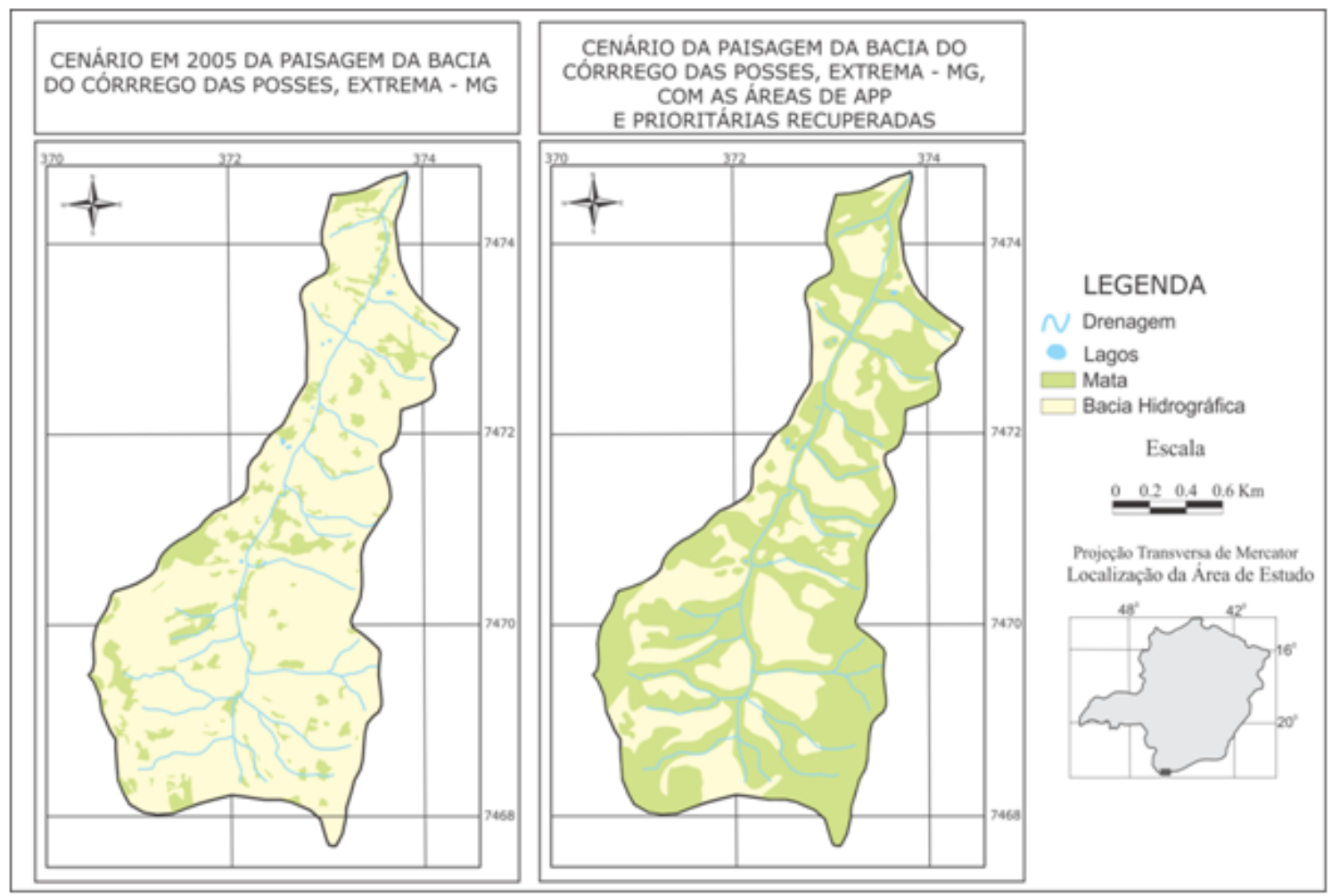

Fonte: $\mathrm{O}$ autor

Esta técnica comprova a eficiência da restauração da paisagem, onde os aspectos positivos são o aumento da área central dos fragmentos que passariam de 110,74 para $550,19 \mathrm{~m}^{2}$, a diminuição do grau de isolamento dos mesmos que seria $58,5 \mathrm{~m}$ e a reestruturação da conectividade estrutural da paisagem.

$\mathrm{Na}$ figura 11, observa-se que, no cenário proposto, a paisagem florestal apresenta-se continua, ou seja, é possível verificar que as florestas não estão segmentadas desde a montante até a jusante da bacia.

Estas constatações permitiriam supor que uma espécie pudesse atravessar a bacia do córrego das Posses de uma ponta à outra da paisagem, locomovendo-se somente dentro de áreas de vegetação nativa.

Entretanto, mesmo que a recuperação da vegetação nativa nas áreas de APP e das áreas prioritárias de recomposição florestal propicie a regularização da paisagem em relação ao Código Florestal, estes instrumentos normativos de comando e controle ainda são insuficientes para manter a conectividade biológica e o grau de fragmentação pequeno da paisagem, pois a porcentagem mínima de vegetação, de $59,29 \%$, exigida para permitir a percolação dos fluxos biológicos (METZGER, 2002), ainda não é atingida pelo cenário proposto, que apresenta $57,84 \%$. 
Assim, considerando o enfoque da conservação da biodiversidade, apenas o estabelecimento de uma rede de fragmentos florestais, distribuídos adequadamente pela bacia do córrego das Posses, ainda não é suficiente para estabelecer um alto nível de fluxo biológico nesta bacia hidrográfica, sendo necessário efetuar o manejo da paisagem de maneira adequada para propiciar uma conectividade biológica maior.

\section{CONSIDERAÇÕES FINAIS}

Os resultados mostram que a bacia hidrográfica do córrego das Posses ainda não está ajustada às determinações do Código Florestal pois, dos 445,75 ha de Áreas de Preservação Permanente previstos, apenas 56,41 ha estão cobertos com matas. O mapeamento das Áreas de Preservação Permanente pelas alíneas do Código Florestal mostrou que as APP's ao redor dos lagos e lagoas são as mais degradadas, com $94,25 \%$ de sua área sendo usada indevidamente. As categorias nascentes, topo de morros, rios e declividade maior do que $45^{\circ}$, apresentam um estágio de degradação de $92,82 \%, 91,75 \%, 81,49 \%$ e $75,44 \%$, respectivamente.

O grande empecilho para que estas normas jurídicas sejam cumpridas são as barreiras econômicas e culturais impostas pelos proprietários. Sendo assim, além dos instrumentos de comando e controle, devem existir outros mecanismos de desenvolvimento e organização territorial baseados em incentivos à preservação destas áreas através da implementação de novos mecanismos econômicos.

Dentre as inúmeras estratégias implantadas para romper estas barreiras, o pagamento por serviços ambientais (PSA) mostra-se a mais aceitável, pois possibilita que os proprietários rurais efetuem a manutenção da cobertura florestal nativa, sem impedimento à ocorrência de práticas agropecuárias. Contudo, vale a pena salientar que o pagamento por serviços ambientais não pode ser considerado como indenização, e sim como uma negociação privada.

Entretanto, para conseguir atrelar as atividades agropecuárias das propriedades rurais com a paisagem, é imprescindível que a discussão para a implantação do PSA seja integrada aos aspectos geográficos, econômicos, ambientais e jurídicos, já que há informações ambientais suficientes para estabelecer as ações prioritárias de restauração e conservação.

O método proposto por Ranieri (2004), associado à utilização de geotecnologias, mostrou-se muito eficaz na delimitação, na quantificação e a caracterização das APP's e das áreas prioritárias de restauração florestal, sendo fundamental para a identificar as possíveis variações da estrutura da paisagem, permitindo a visualização de cenários futuros que podem ser utilizados na tomada de decisões sobre a ocupação do território. A partir deste procedimento metodológico, a restauração florestal pode se apoiar em instrumentos baseados em critérios ecológicos e jurídicos que minimizam a subjetividade, aumentando a transparência no processo de gestão por parte dos proprietários rurais e os órgãos de fomento. Entretanto, para a bacia das Posses, a regularização das propriedades com relação ao Código Florestal é suficiente para manter a conectividade estrutural da paisagem, contudo não é suficiente para manter a conectividade biológica da 
mesma, pois mesmo tornando-a conectada da montante à jusante, ainda assim a área de matas não atingiria o limite mínimo estatisticamente definido para que houvesse percolação de uma maneira eficiente e satisfatória.

Contudo, do ponto de vista prático, a possibilidade persuasiva das medidas de comando e controle de influenciarem e reestruturarem a ocupação do uso da terra, dentro de uma prospectiva territorial sustentável, ainda fica fadada aos interesses econômicos que se apresentam praticamente como o único fator determinante na organização do espaço rural.

\section{REFERÊNCIAS BIBLIOGRÁFICAS}

AHRENS, S. Sobre a legislação aplicável à restauração de florestas de preservação permanente e de reserva legal. In: GALVÃO, A. P. M.; PORFíLIO-DA-SILVA, V. (Ed) Restauração Florestal: fundamentos e estudos de caso, Colombo: Embrapa Florestas, 2005. p. 13-26.

ANDERSON, A. B.; JENKINS, C. N. Applying nature's design: corridors as strategy of biodiversity conservation. New York: Columbia University Press, 2005. $229 \mathrm{p}$.

ARAÚJO, M. A. R. Unidades de conservação no Brasil: da república à gestão de classe mundial. Belo Horizonte: SEGRAC, 2007. 272p.

AUTODESK MAP 5, Inc. Autocad Map Release 5: user's guide, EUA. 2000.

AZEVEDO, T. S. Análise espaço temporal da dimensão fractal das matas ciliares na alta bacia do rio Passa Cinco - Centro Leste do Estado de São Paulo. 2003. 161f. Dissertação (Mestrado em Geografia). Instituto de Geociências e Ciências Exatas, Universidade Estadual Paulista, Rio Claro - SP.

AZEVEDO, T. S.; MANZATTO, A. G. Caracterização fitogeográfica de seis bacias hidrográficas localizadas no município de Extrema (MG). In: VII Congresso de Ecologia do Brasil, 2005, Anais... Caxambú: 2005 - cd rom.

BRASIL Projeto Radam Brasil: levantamento de recursos naturais Folhas SF.23/24 (Rio de Janeiro/Vitória). Rio de Janeiro: 1983. v. 32. 775p.

BRASIL RESOLUÇÃO CONAMA No 004, DE 18 DE SETEMBRO DE 1985. Diário Oficial da União, Brasília: 20 de Janeiro de 1986. 1985. Disponível em: <http://www.mma.gov.br/port/conama/legi.efm>. Acesso em: 15 de Abril de 2017.

BRASIL RESOLUÇÃO CONAMA Nº20, DE 18 DE JUNHO DE 1986.

Diário Oficial da União, Brasília: 30 de Julho de 1986. 1986. Disponível em: <http://www.mma.gov.br/port/conama/legi.efm>. Acesso em: 15 de Abril de 2017.

BRASIL MEDIDA PROVISÓRIA No 1.956-50, DE 26 de MAIO de 2000. Diário Oficial da União, Brasília: 26 de Maio de 2000. 2000. Disponível em: <http://legislacao.planalto.gov.br>. Acesso em: 15 de Abril de 2017.

BRASIL RESOLUÇÃO CONAMA No 302, DE 20 DE MARÇO DE 2002. Diário Oficial da União, Brasília: 13 de Maio de 2002. 2002a. Disponível em: <http://www.mma.gov.br/port/conama/legi.efm>. Acesso em: 15 de Abril de 2017.

Estudos Geográficos, Rio Claro, 15(2): p-p, jul./dez. 2017 (ISSN 1678-698X)

http://www.periodicos.rc.biblioteca.unesp.br/index.php/estgeo 
BRASIL RESOLUÇÃO CONAMA No 303, DE 20 DE MARÇO DE 2002. Diário Oficial da União, Brasília: 13 de Maio de 2002. 2002b. Disponível em: <http://www.mma.gov.br/port/conama/legi.efm>. Acesso em: 15 de Abril de 2017.

BRASIL RESOLUÇAO CONAMA No 369, DE 28 DE MARÇO DE 2006. Diário Oficial da União, Brasília: 29 de Março de 2006. 2006. Disponível em: <http://www.mma.gov.br/port/conama/legi.efm>. Acesso em: 10 de Fevereiro de 2017.

BRASIL Ministério de Fazenda Imposto sobre a propriedade rural: manual de preenchimento da declaração. 2007. 52p. Disponível em: <www.receita.fazenda.gov.br>. Acesso em: 12 de Janeiro de 2017.

BRASIL LEI FEDERAL N $N^{0}$ 12.651, DE 28 DE MAIO DE 2012. Diário Oficial da União, Brasília: 28 de maio de 2012. Disponível em: < http://www.planalto.gov.br/ccivil_03/_ato2011-2014/2012/lei/l12651.htm>. Acesso em 02 de Fevereiro de 2017.

CHRISTOFOLETTI, A. Geomorfologia. São Paulo: Edgard Blücher, 2ª Ed., 1980. $188 p$.

DOREMUS, H. A policy portifolio approach to biodiversity protection on private lands. Environmental Science and Policy. v. 6, p.217-232. 2003.

ENGEL, V. L.; PARROTTA, J. A. Definindo a restauração ecológica: tendências e perpectivas mundiais. In: J.A. KAGEYAMA, P. Y. et al (Ed.) Restauração Ecológica de Ecossistemas Naturais, Botucatu: FEPAF, 2003 p. 1- 27

EASTMAN, J. R. Idrisi for windows: user's guide. Worcester: Departament of Geography of Clark University, 1999. v.2.

EXTREMA (Cidade) Departamento de meio ambiente. Projeto água é vida: diagnóstico sócio ambiental em sub bacias hidrográficas no município de Extrema: 2005a. Disponível em: <http://www.extrema.mg.gov.br/meioambiente/index.php>. Acesso em: 14 de Fevereiro de 2017.

EXTREMA (Cidade) Departamento de meio ambiente. Projeto Conservador das Águas Lei Municipal 2.001/05: 2005b. Disponível em: <http://www.camaraextrema.mg.gov.br/html/legislacao>. Acesso em 14 de Fevereiro de 2017.

EXTREMA (Cidade) EXTREMA Plano Diretor Lei Municipal 1574/01: 2001, 77 p. Disponível em: <http://www.camaraextrema.mg.gov.br/html/legislacao>.

Acesso em 14 de Fevereiro de 2017.

EXTREMA (Cidade) DECRETO n 1801 de 01 de SETEMBRO de 2006 (2006). Disponível em: <http://www.camaraextrema.mg.gov.br/html/legislacao>. Acesso em 14 de Fevereiro de 2017.

FAO Forest Resources Assessment 2000: Main Report. Rome: FAO Forestry Paper. 2001, 140p.

FORMAN, R. T. T.; GODRON, M. Landscape Ecology. New York: Wiley, 1986. $619 p$. 
FORMAN, R. T. T. Land Mosaics: the ecology of landscapes and regions. New York: Cambridge University Press, 1995. p. 43-142.

HOEFFEL, J. L. M et al. Área de Proteção Ambiental (APA) Fernão Dias/MG Transformações socioambientais na bacia hidrográfica do rio Jaguary. Climep, Rio Claro. v. 3, n.1, p. $30-60,2008$.

INSTITUTO BRASILEIRO DE GEOGRAF IA E ESTATÍSTICA (IBGE) - Enciclopédia dos Municípios Brasileiros. Rio de Janeiro: 1959. v. 25. 474p. Disponível em: <http://biblioteca.ibge.gov.br/coleção_digital_publicacoes.php>. Acesso: 12 de Janeiro de 2017.

INSTITUTO BRASILEIRO DE GEOGRAFIA E ESTATÍSTICA (IBGE) -Censo Demográfico de Minas Gerais. Rio de Janeiro: 1970. Disponível em:

<http://biblioteca.ibge.gov.br/coleção_digital_publicacoes.php>. Acesso: 12 de Janeiro de 2017.

INSTITUTO BRASILEIRO DE GEOGRAFIA E ESTATÍSTICA (IBGE) - Censo Demográfico de Minas Gerais. Rio de Janeiro: 1985. Disponível em:

<http://biblioteca.ibge.gov.br/coleção_digital_publicacoes.php>.

acesso: 12 de Janeiro de 2017.

INSTITUTO BRASILEIRO DE GEOGRAFIA E ESTATÍSTICA (IBGE) - Censo Demográfico de Minas Gerais. Rio de Janeiro: 1995. Disponível em:

<http://biblioteca.ibge.gov.br/coleção_digital_publicacoes.php>.

Acesso: 12 de Janeiro de 2017.

INSTITUTO BRASILEIRO DE GEOGRAFIA E ESTATÍSTICA (IBGE) - Censo Agropecuário de Minas Gerais. Rio de Janeiro: 2006. Disponível em:

$<w w w . i b g e . g o v / h o m e / e s t a t i s t i c a / e c o n o m i a / a g r o p e c u a r i a / c e n s o a g r o / 2006 / d e f o u t . s h t$ m>. Acesso: 12 de Janeiro de 2017.

INSTITUTO NACIONAL DE PESQUISAS ESPACIAIS (INPE) - Divisão de Processamento de Imagens. Introdução ao SPRING: apresentação. São José dos Campos: $\quad$ INPE. 2001. Disponível em: <http://www.dpi.inpe.br/spring/portugues/manuais.html>.

Acesso em: 15 de Abril de 2017.

JESUS, N. Inter-relação entre geologia/relevo/solo/vegetação e atuação dos processos morfodinâmicos da unidade paisagem serra do japi: uma contribuição à conservação. 2004. 189f. Tese (Doutorado em Geociências). Instituto de Geociências e Ciências Exatas, Universidade Estadual Paulista, Rio Claro - SP.

JOELS, L. M Reserva Legal e gestão ambiental da propriedade rural: um estudo comparativo da atitude e comportamento de agricultores orgânicos e convencionais do distrito federal. Planeta Orgânico. 2002. Disponível em: <http://www.planetaorganico.com.br/trabjoels2.htm>. Acesso em 13 de Março de 2017. 
KAGEYAMA, P. Y. et al. Biodiversidade e restauração da floresta tropical. In: KAGEYAMA, P. Y. et al (Ed.) Restauração Ecológica de Ecossistemas Naturais, Botucatu: FEPAF, 2003 p. 49 - 76.

KAGEYAMA, P. Y et al. Carta de Piracicaba: I fórum sobre APP e RL na paisagem e propriedade rural. Piracicaba: ESALQ/USP.2007. Disponível em:

$<$ http://sigam.ambiente.sp.gov.br/sigam2/repositorio/126/documentos/carta20\%de20 \%piracicaba.pdf>. Acesso em maio de 2017.

LAURENCE, R.; Edge effects in tropical forest fragments: application of model for the design of nature reverses. Biological Conservation, Cambridge, v. 57, p. 205-219, 1991.

LI, BAI-LAN Fractal geometry applications in description and analysis of patch patterns and patch dynamics. Ecological Modeling, Copenhagen, v. 132, p. 33-50, 2000.

MaCARTHUR, R. H.; WILSON, E. O. The theory of island biogeography New Jersey: Princeton University Press, 1967. p.203.

McGARRIGAL, k.; MARKS, B. J. FRAGSTATS: spatial pattern analysis program for quantifying landscape structure. Gen. Tech. Rep. PNWGTR- 351. Portland: U. S. Department of Agriculture Forest Service. 1995, 122p.

METZGER et al. Os caminhos da biodiversidade. Ciência Hoje, v. 25, n.146, p. 6264, 1999.

METZGER, J. P. Bases biológicas para a "reserva legal". Ciência Hoje, v. 31, n.183, p. 48-49, 2002.

METZGER, J. P. Como restaurar a conectividade de paisagens fragmentadas. In: J.A. KAGEYAMA, P. Y. et al (Ed.) Restauração Ecológica de Ecossistemas Naturais, Botucatu: FEPAF, 2003 p. 49-76.

MINAS GERAIS (Estado) LEI ESTADUAL N 14.309, DE 19 DE JUNHO DE 2002. Disponível em: <http://www.semad.mg.gov.br>. Acesso em: 17 de Janeiro de 2017.

MONTGOMERY, R. D.; GRANT, G. E.; SULLNAN, K. - Watershed analysis as a framework for implementing ecosystem management. Water Resources Bulletin, v. 31, n. 3, p. $369-386,1995$.

NASCIMENTO, L. A. et al. Delimitação automática de áreas de preservação permanente (APP) e identificação de conflito de uso da terra na bacia hidrográfica do rio Alegre. In: XIII SIMPÓSIO BRAS ILE IRO DE SENSORIAMENTO REMOTO, 2005, Anais... Goiânia: 2005. p.4081 - 4087.

PICKETT, S. T. A.; KEVIN, H. R. Patch dynamics: the transformation of landscape structure and function. In: BISSONETTE, J. A. (Ed.) New York: Springer Verlag, 1997. p. 101-128.

PINTO, L. A. V. et al. Caracterização física da bacia hidrográfica do ribeirão Santa Cruz. Lavras, MG e uso conflitante da terra em suas Áreas de Preservação Permanente. Lavras: Cerne, v.11, n 1, 49-60, 2005. 
PRIMACK, R. B.; RODRIGUES, E. Biologia da conservação. Londrina: E. Rodrigues, 2001. 328p.

RAMOS FILHO, L. O. Uso de sistemas agroflorestais para recuperação de APP e Reserva Legal na agricultura familiar. Sumário de palestra apresentada no I fórum sobre APP e RL na paisagem e propriedade rural. Piracicaba: ESALQ/USP. $2007 . \quad$ Disponível em: <http://sigam.ambiente.sp.gov.br/sigam2/repositorio/126/documentos/luiz_octavio_ra mos_resumo.pdf>. Acesso em maio de 2017.

RANIERI, V. E. L. Reservas Legais: critérios para localização e aspectos de gestão. 2004. 149f. Tese (Doutorado em Engenharia). Escola de Engenharia de São Carlos, Universidade de São Paulo, São Carlos - SP.

REX, K. D.; MALANSON, G. P. The fractal shape of riparian forest patches. Landscape Ecology, Hague, v. 4, n. 4, p. 249-258, 1990.

RIBEIRO, C. A. A. S. et al. O desafio da delimitação de áreas de preservação permanente Revista Arvore, Viçosa, v.29, n 2, 203- 212, 2005.

SHELHAS, J.; GREENBERG, R. Forest Patches in Tropical Landscapes. Washington D.C.: Islands Press, 1996. p. 151-167.

SOARES et al. Aplicação de geotecnologias na identificação de conflitos entre o uso da terra e a legislação ambiental. In: XIII SIMPÓSIO BRASILEIRO DE SENSORIAMENTO REMOTO, 2007, Anais... Floria nópolis: 2007. p. 2651 - 1657.

STEVAUX, J. C.; LATRUBESSE, E. M. Geomorfologia fluvial. São Paulo: Oficina de Textos, 2017. 336p.

STRAHLER, A. N. Dynamic basis of geomorphology Bulletin of the Geological Society of America, v.63, p. $923-938,1952$.

TABARELLI, M.; et al. Effects of habitat fragmentation on plant guid structure in the montane Atlantic forest of southeastern Brasil. Biological Conservation. New York, v. 91, p. 119-127, 1999.

TABANEZ, A. J. A. Ecologia e manejo de ecounidades em um fragmento florestal na região de Piracicaba, SP. 1995. 85f., Dissertação (Mestrado em Ciências Florestais), Instituto, Escola Superior de Agricultura Luiz de Queiroz, Universidade de São Paulo, Piracicaba, 1995.

TURNER, M. G.; Gardner, R. H. Quantitative methods in landscape ecology: an introduction. In: TURNER, M. G.; GAEDNER, R H. (Ed.), Quantitative methods in landscape ecology, New York: Springer Verlag, 1990. p. 3-14.

TURNER, M. G. et al. Landscape ecology in theory and practice: pattern on process. New York: Springer Verlag, 2001. 401p.

VIANA, V. M.; TABANEZ, A. J. A.; MARTINEZ, J. L. A. Restauração e Manejo de Fragmentos Florestais. Revista do Instituto Florestal, Edição Especial. São Paulo, v 3, pt. 3, p. $400-407,1992$.

VIANA, V. M.; TABANEZ, A. J. A.; DIAS, A. S. Consequências da fragmentação e do efeito de borda sobre a estrutura, diversidade e sustentabilidade de um 
O uso da legislação ambiental na restauração...

fragmento de floresta de planalto de Piracicaba, SP. Revista Brasileira de Biologia, São Carlos, v. 57. p. 47-60, 1997.

WIENS et al. Patchy landscapes and animal movements: do Beetles percolate? Oikos, v. 78, p. 257-264, 1997. 